\title{
Differential Expression of Brain-Derived Neurotrophic Factor, Neurotrophin-3, and Neurotrophin-4/5 in the Adult Rat Spinal Cord: Regulation by the Glutamate Receptor Agonist Kainic Acid
}

\author{
Isobel A. Scarisbrick, ${ }^{1,2}$ Paul J. Isackson, ${ }^{1}$ and Anthony J. Windebank ${ }^{2}$ \\ ${ }^{1}$ Department of Biochemistry and Molecular Biology, Mayo Clinic Jacksonville, Jacksonville, Florida 32224, and \\ ${ }_{2}^{2}$ Molecular Neuroscience Research, Mayo Clinic Rochester, Rochester, Minnesota 55905
}

\begin{abstract}
Previous in vitro studies indicate that select members of the neurotrophin gene family, namely brain-derived neurotrophic factor (BDNF), neurotrophin-3 (NT-3), and neurotrophin-4/5 (NT$4 / 5)$, contribute to survival and differentiation of spinal cord motoneurons. To investigate the potential roles of these factors in the adult spinal cord, we examined their cellular localization and regulation after systemic exposure to an excitotoxic stimulus, kainic acid (KA).

Of the neurotrophins examined, NT-4/5 mRNA was most robustly expressed in the lumbosacral spinal cord of the normal adult rat, including expression by neurons throughout the gray matter, and in a subpopulation of white and gray matter glia. Both BDNF and NT-3 mRNAs were also densely expressed by $\alpha$ motoneurons of lamina IX, but were detected at lower levels
\end{abstract}

The neurotrophins are a family of related signaling proteins that regulate survival and differentiation of select neurons. Brainderived neurotrophic factor (BDNF), neurotrophin-3 (NT-3), and neurotrophin-4/5 (NT-4/5), but not nerve growth factor (NGF), prevent motoneuron death in cultures of embryonic motoneurons (Henderson et al., 1993; Kaal et al., 1997; Becker et al., 1998) during embryogenesis (Oppenheim et al., 1992) and in the postnatal period (Sendtner et al., 1992; Yan et al., 1992; Hughes et al., 1993; Koliatsos et al., 1993, 1994; Li et al., 1994; Vejsada et al., 1994, 1995). Evidence for physiological activity of neurotrophins in the adult cord includes the expression of p75-NGFR, TrkB and TrkC components of the neurotrophin receptor signaling system by cord motoneurons (Frisen et al., 1992; Merlio et al., 1992; Funakoshi et al., 1993; Koliatsos et al., 1993; Seeburger et al., 1993). Additionally, BDNF (Koliatsos et al., 1993), NT-4/5 (Koliatsos et al., 1994), and NT-3 (Maisonpierre et al., 1990a) are produced in skeletal muscle targets of motoneurons, and their expression in muscle is regulated by activity, and peripheral nerve injury (Funakoshi et al., 1993, 1995). In the case of nerve injury, exogenous BDNF and NT-4/5 attenuate degeneration and bio-

\footnotetext{
Received March 3, 1999; revised June 7, 1999; accepted July 7, 1999.

This work was supported by the Mayo Foundation. I.A.S. was supported by a Research Fellowship from Nemours Children's Clinic. We thank Mr. M. Schreiber, of Mayo Visual Information, for assistance with the photographic prints and Dr. D. McGavern for writing the program for the KS400 software. The hybridoma (NS-1), developed by Dr. S. Hockfield, was obtained from the Developmental Studies Hybridoma Bank maintained by The University of Iowa, Department of Biological Sciences, Iowa City, IA 52242, under contract NO1-HD-7-3263 from the National Institute of Child Health and Human Development.

Correspondence should be addressed to Dr. Isobel A. Scarisbrick, Neuroscience Research, 442 D Guggenheim Building, Mayo Clinic Rochester, 200 First Street Southwest, Rochester, MN 55905.

Copyright (C) 1999 Society for Neuroscience 0270-6474/99/197757-13\$05.00/0
}

elsewhere in the gray matter. NT-3 mRNA was additionally expressed by spinal cord glia, but was less widespread compared to NT-4/5. In response to systemic administration of KA, NT- $4 / 5$ and BDNF mRNAs were dramatically upregulated in a spatially and temporally restricted fashion, whereas levels of NT-3 mRNA were unchanged. These results provide strong in vivo evidence to support the idea that BDNF, NT-3, and in particular, NT-4/5, play a role in the normal function of the adult spinal cord. Furthermore, our results indicate that the actions of BDNF and NT-4/5 participate in the response of the cord to excitotoxic stimuli, and that those of NT- $4 / 5$ and NT-3 include both neurons and glia.

Key words: neurotrophin; motoneuron; glia; oligodendrocyte; kainic acid; spinal cord injury

chemical changes in affected neurons (Chiu et al., 1994; Yan et al., 1994; Friedman et al., 1995; Kishino et al., 1997).

Excitotoxic events caused by excess glutamate receptor activation result in degeneration within select neuronal populations, including the hippocampus (Olney, 1978), striatum (Frim et al., 1993), and spinal cord (Chase et al., 1985; Pisharodi and Nauta, 1985; Hugon et al., 1989; Nag and Riopelle, 1990; Stewart et al., 1991). Glutamate is the major excitatory neurotransmitter of projection neurons and dorsal root afferents entering the cord, and excessive release of glutamate, or breakdown in glutamate metabolism, are implicated in neuronal death associated with spinal cord trauma, ischemia, and amyotrophic lateral sclerosis (ALS) (Rothstein et al., 1990; Marsala et al., 1994; Rokkas et al., 1994). Motoneurons are vulnerable to AMPA/kainate receptormediated injury because of expression of AMPA/kainate receptors gating channels with direct $\mathrm{Ca}^{2+}$ permeability (Carriedo et al., 1996). Importantly, excitatory amino acid antagonists protect against deficits associated with spinal cord trauma, ischemia (Simon et al., 1984; Faden et al., 1988, 1990; Gomez-Pinilla et al., 1989; Martinez-Arizala et al., 1990; Wrathall et al., 1994), and axotomy (Mentis et al., 1993).

Efforts have been made to determine the clinical significance of neurotrophins in spinal cord degenerative disorders, such as ALS, however little is known about cell-specific expression patterns, or potential roles, of these factors in the normal or injured adult cord. In the present study, the potential sites of activity of the neurotrophins that affect motoneuron survival, that is BDNF, NT-3, and NT-4/5, were examined by in situ hybridization histochemistry in the normal adult rat spinal cord. In parallel, we tested whether the expression of each was regulated by systemic administration of the excitotoxic stimulus kainic acid (KA). The 
results of these studies are important to the development of therapeutic strategies to mitigate excitotoxic sequelae that occur in spinal cord injury or disease.

\section{MATERIALS AND METHODS}

Adult male Sprague Dawley rats (180-200 gm) (Harlan Sprague Dawley, Indianapolis, IN) were administered the KA/AMPA excitatory amino acid receptor agonist, kainic acid (KA) $(10 \mathrm{mg} / \mathrm{kg}$, i.p.). Animals were monitored for behavioral changes and excluded from the study if physical seizures were not observed. Control animals were administered a similar volume of physiological saline. At 4, 24, 72 and $168 \mathrm{hr}$ after administration of KA or saline, animals were deeply anesthetized with sodium pentobarbital $(50 \mathrm{mg} / \mathrm{kg})$, and perfused transcardially with physiological saline followed by $4.0 \%$ paraformaldehyde in $0.1 \mathrm{~m}$ phosphate buffer. The lumbosacral enlargement of the spinal cord (L1 to S1) was removed and post-fixed for $24 \mathrm{hr}$ in $4.0 \%$ paraformaldehyde. Spinal cords were cryoprotected in $25.0 \%$ sucrose in $4.0 \%$ paraformaldehyde before being frozen on dry ice and cut in the transverse plane at a thickness of $20 \mu \mathrm{m}$. Sections were collected in series of 12 into $4.0 \%$ paraformaldehyde and stored at $4^{\circ} \mathrm{C}$ before in situ hybridization histochemistry.

The cDNA clones used to produce BDNF, NT-3, and NT-4/5 riboprobes were generated in our laboratory, are the same as those used in previous studies, and each are complementary to the coding regions of the mature neurotrophins (Isackson et al., 1991a,b; Scarisbrick et al., 1994). Plasmid CT53-12, containing 408 base pairs (bp) of mouse NT-4/5 (nucleotides 263-671; Ip et al., 1992), was linearized with BamHI and transcription-labeled using T3 RNA polymerase for the antisense probe. The sense probe was generated from $P v u$ II-linearized CT53-12 with T7 RNA polymerase. pR112-8 contains $384 \mathrm{bp}$ coding for mature rat BDNF (nucleotides 388-771; Timmusk et al., 1993). PvuII-digested pR112-8 was used to produce the BDNF antisense probe with T3 RNA polymerase and the sense probe with T7 RNA polymerase. pRNT3-1 contains a 392 bp insert encoding mature rat NT-3 (nucleotides 481-873; Maisonpierre et al., 1990b). Antisense and sense strand NT-3 RNA probes were prepared from $P v u$ II-linearized pRNT3-1 with T3 or T7 RNA polymerase, respectively. In vitro transcription for the generation of radioactive probes was accomplished in the presence of $\alpha-\left[{ }^{35} \mathrm{~S}\right]-\mathrm{UTP}$ (Amersham, Arlington Heights, IL), and in the presence of digoxigenin (DIG)-11UTP (Boehringer Mannheim, Indianapolis, IN) for the generation of DIG-labeled RNA probes. All restriction and transcription enzymes were obtained from Stratagene (La Jolla, CA).

In situ hybridization of ${ }^{35} \mathrm{~S}$-labeled riboprobes was carried out by previously published methods (Scarisbrick et al., 1993, 1997). In each experiment, slides containing spinal cord sections encompassing the L1-S1 segments, from control or experimental animals, at each time point, were processed in parallel. Hybridization buffer containing 50\% deionized formamide, $10 \%$ dextran sulfate, $0.7 \%$ ficoll, $0.7 \%$ polyvinyl pyrrolidone, $0.7 \%$ bovine serum albumin, $0.15 \mathrm{mg} / \mathrm{ml}$ yeast transfer RNA, $0.33 \mathrm{mg} / \mathrm{ml}$ denatured salmon sperm DNA, $40 \mathrm{~mm}$ dithiothreitol (DTT), and the ${ }^{35} \mathrm{~S}$-labeled cRNA at a concentration of $1 \times 10^{6} \mathrm{cpm} / 100$ $\mathrm{ml}$ of hybridization solution, was applied to slide-mounted sections. Tissue sections were coverslipped and hybridized at $60^{\circ} \mathrm{C}$ for $36 \mathrm{hr}$. After hybridization, coverslips were removed by soaking tissue sections in $4 \times$ $\mathrm{SSC}$ for $1 \mathrm{hr}$ at $60^{\circ} \mathrm{C}(1 \times \mathrm{SSC}=0.15 \mathrm{M} \mathrm{NaCl}, 0.015 \mathrm{~m}$ sodium citrate, $\mathrm{pH}$ 7.0). After treatment of sections with $30 \mathrm{mg} / \mathrm{ml}$ ribonuclease A (Sigma, St. Louis, MO) in $10 \mathrm{~mm}$ Tris-saline with $1 \mathrm{~mm}$ EDTA for $30 \mathrm{~min}$ at $45^{\circ} \mathrm{C}$, tissue sections were then washed through SSC solutions of increasing stringency containing $100 \mathrm{~mm}$ sodium thiosulfate to a final stringency of $0.01 \times \mathrm{SSC}$ at $60^{\circ} \mathrm{C}$ for $1 \mathrm{hr}$, and then in $0.01 \times \mathrm{SSC}$ at room temperature for 12-24 hr. The distribution of cRNA hybridization was initially visualized by film autoradiography ( $\beta$ Max Hyperfilm; Amersham). Tissue sections were then defatted in chloroform and processed for emulsion autoradiography (NTB2), with exposure at $4^{\circ} \mathrm{C}$ for $21 \mathrm{~d}$. Sections were developed in Kodak (Eastman Kodak, Rochester, NY) D19, fixed, and stained with $0.25 \%$ cresyl violet. A series of sections adjacent to those processed for in situ hybridization histochemistry, were counterstained with $0.25 \%$ cresyl violet without further processing. Segmental levels within the lumbosacral enlargement were confirmed in these series of sections by comparison to cytoarchitectural features described by Molander and Grant (1995).

The relative amount of cRNA hybridization in each case was determined by densitometric analysis of film autoradiograms using the MCID image analysis system (Imaging Research, St. Catherines, Ontario). Calibration and linearization of film autoradiograms were established relative to $\mathrm{C}^{14}$-labeled autoradiographic standards containing known counts per minute, which were exposed to each film simultaneously with hybridized tissue sections. Images of hybridized spinal cord sections taken from film autoradiographs were enlarged by a factor of 48 , and multiple densitometric measurements, of a $4 \mathrm{~mm}^{2}$ area, were made in regions encompassing either the dorsal, lateral, and ventral white matter, the dorsal gray matter, or the ventral gray matter of the lumbosacral spinal cord. At least 10 tissue sections, spanning the L1-S1 spinal cord segments, were examined from each animal ( $n=3$ to 6 per time point), and from which 40-60 densitometric measurements were taken throughout each region. Changes in cRNA hybridization after intraperitoneal injection of KA were quantified by determining the percent difference in relative optical density (ROD) in control tissue sections relative to experimental tissue sections processed in parallel. The statistical significance of KA-induced changes in neurotrophin mRNA labeling was evaluated by one-way ANOVA of the mean percent control of at least three animals at each time point, followed by the Student-Newman-Keuls post hoc test for paired comparisons. Differences were considered significant when $p$ was $<0.05$ and were expressed as mean \pm SE.

Quantitative analysis of the potential histopathological changes caused by KA on the number and size of ventral horn $\alpha$ motoneurons, and on total cord area, were determined in the series of cresyl violet-stained sections from each animal, which were otherwise unprocessed. Measurements for cord area assessment were calculated from at least four sections through the L3/L4 spinal segments per animal, using an Olympus AX70 microscope $(1.25 \times$ objective $)$ fitted with a SPOT color digital camera (Diagnostic Instruments, Inc., Sterling Heights, MI), to digitize spinal cord images. The perimeter of the cord and the perimeter of the gray matter, were outlined with the aid of a digitizing tablet, and the area was calculated using the KS400 image analysis software (Kontron Elektronik Gmbh, Munich, Germany). The area of white matter was calculated as the difference between total cord area, minus the area of gray matter. For assessment of $\alpha$ motoneuron size and number, digitized images of the ventrolateral motor cell column were collected as above, but using a $20 \times$ objective, from each side of the cord, and from the same sections that were used for evaluation of cord area. Only those motoneurons with a nucleolus in the plane of focus were outlined, such that all measurements were made in planes of section near the somal center. From this outline, which followed an imaginary ellipse within the confines of the cell body, the area, as well as the major and minor diameters were calculated using the KS400 image analysis software. To exclude the possibility of inclusion of $\gamma$ motoneurons and interneurons in the analysis, only those motoneurons $>30 \mu \mathrm{m}$, and therefore likely to be $\alpha$ motoneurons (Peyronnard et al., 1986), were measured.

Colocalization of NT-4/5 mRNA and the oligodendrocyte marker Rip, was accomplished by combining the hybridization of DIG-labeled NT$4 / 5$ cRNA probes, with the visualization of the Rip antigen (Friedman et al., 1989; Jhaveri et al., 1992), using immunofluorescence. Slide-mounted spinal cord sections from control animals were pretreated as above and hybridized in the same buffer, excluding the DTT, and replacing the ${ }^{35} \mathrm{~S}$-labeled riboprobe with $50 \mathrm{pg} / \mu \mathrm{l}$ of antisense or sense stand NT-4/5 DIG-labeled cRNA. Slides were coverslipped and hybridized for $20 \mathrm{hr}$ at $55^{\circ} \mathrm{C}$. Sections were rinsed in $2 \times \mathrm{SSC}$ at $53^{\circ} \mathrm{C}$, and treated with ribonuclease A (Sigma) as above. Tissue was then washed in descending concentrations of SSC to a final wash in $0.5 \times \mathrm{SSC}$ at $53^{\circ} \mathrm{C}$. Hybridized DIG-labeled NT-4/5 cRNA was localized using alkaline phosphataseconjugated sheep anti-DIG IgG Fab fragments, with nitroblue tetrazolium as the chromagen, following the manufacturer's recommendations, producing a blue reaction product at sites of mRNA hybridization (Boehringer Mannheim). Tissue sections were then extensively washed in PBS $(0.1 \mathrm{M})$, and preincubated in PBS containing 3.0\% normal goat serum. The Rip antibody, isolated and purified from hybridoma cell culture supernatant (NS-1; Developmental Studies Hybridoma Bank, University of Iowa), was diluted in the preincubation buffer at a concentration of $10 \mu \mathrm{g} / \mathrm{ml}$ and applied to DIG-labeled sections at $4^{\circ} \mathrm{C}$ for $12 \mathrm{hr}$. Sections were washed in PBS, and the Rip antigen was visualized using rhodamine-conjugated goat anti-mouse IgG (1:100; Jackson ImmunoResearch, West Grove, PA). Tissue sections were washed in PBS and coverslipped with $90.0 \%$ glycerol, $\mathrm{pH}$ 8.0, and viewed on an LSM 310 Confocal Microscope (Carl Zeiss Inc., Oberkochen, Germany), with either transmitted light to view DIG-labeled NT-4/5 cRNA, or at a wavelength of $568 \mathrm{~nm}$ to view the rhodamine-labeled Rip antibody. 

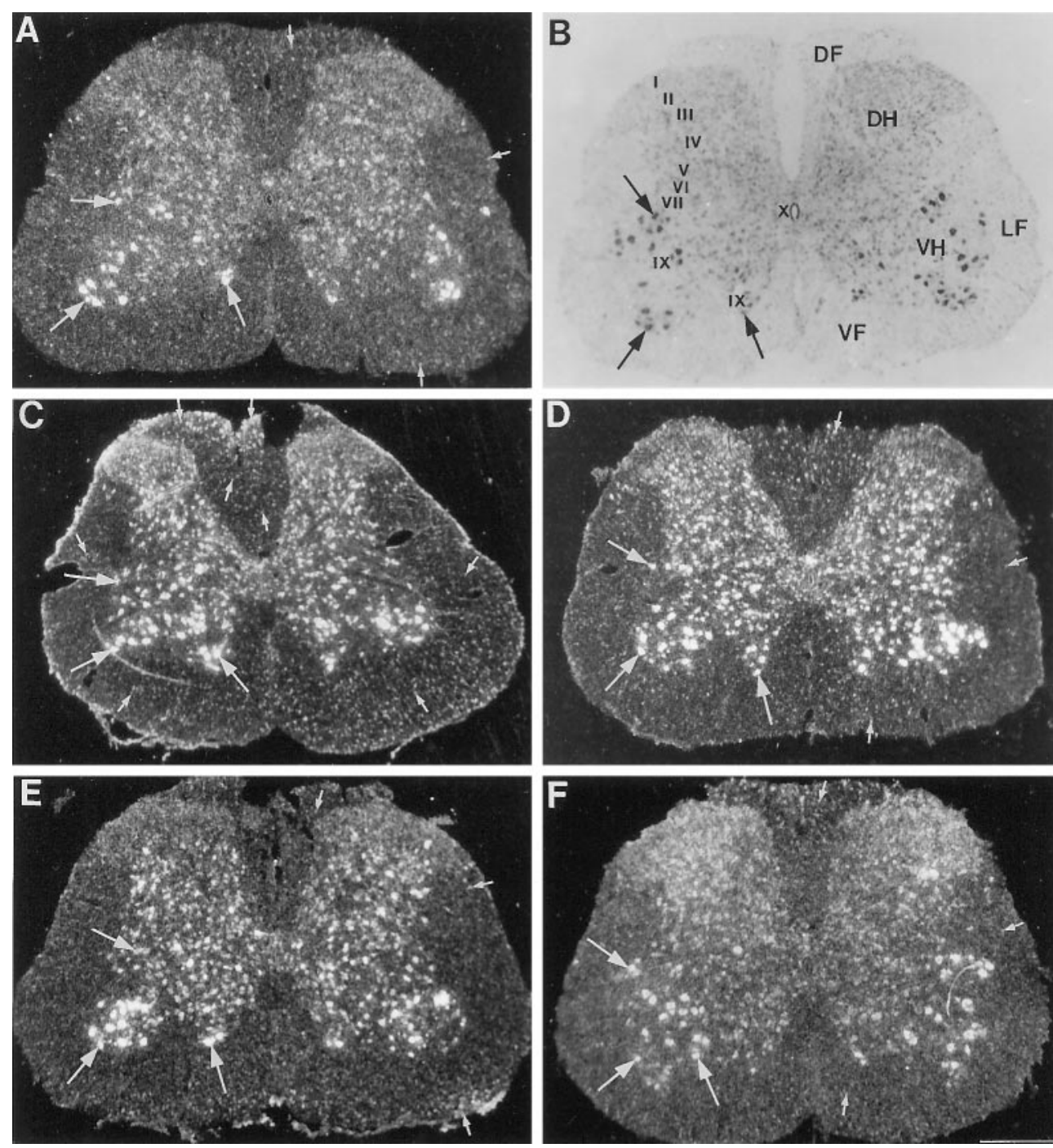

Figure 1. NT-4/5 mRNA expression was robust throughout all regions of the adult rat lumbosacral spinal cord and was differentially upregulated by systemic KA. Dark-field photomicrographs show the autoradiographic localization of hybridization to NT-4/5 mRNA in representative transverse sections at the L3/L4 level of the spinal cord of a control rat $(A)$, and in parallel sections of paired experimental rats at $4(C), 24(D), 72$ $(E)$, or $168 \mathrm{hr}(F)$ after intraperitoneal administration of KA. Bright-field photomicrograph $(B)$, shows the appearance of Nissl-stained cellular elements in the dorsal $(D F)$, lateral $(L F)$, and ventral funiculi $(V F)$ of the white matter, and in laminae I-X of the gray matter, in a parallel section from a control animal. There was a significant increase in density of autoradiographic grains (seen here as white under dark-field illumination), overlying the dorsal horn $(D H)$, and in the white matter funiculi, of spinal cord sections from animals at $4 \mathrm{hr}(C)$ relative to control $(A)$ (Fig. $8 B)$. NT-4/5 mRNA labeling was also elevated in the dorsal horn relative to controls when examined at $72(E)$ and $168 \mathrm{hr}(F)$ after KA administration (Fig. 5). Large arrows indicate position of lamina IX motoneurons. Small arrows indicate NT-4/5 mRNA hybridization by white matter glia. $V H$, Ventral horn. Scale bar, $500 \mu \mathrm{m}$.

\section{RESULTS}

\section{Neurotrophin mRNA expression in the normal adult rat lumbosacral spinal cord}

Neurotrophin-4/5 mRNA was densely expressed in all regions of the normal adult rat lumbosacral spinal cord (Fig. 1). Cells hybridizing high levels of NT-4/5 cRNA were found in both the dorsal and ventral horns, and included both neurons and neuroglia (Fig. 1 $A$; see Figs. 6-9). In the dorsal horn, the highest levels of autoradiographic labeling of NT-4/5 mRNA were observed in laminae III-VII, with lower levels in laminae I and II (Fig. 1A). NT-4/5 mRNA labeling was dense in cells in all laminae of the ventral horn. The $\alpha$ motoneurons of the medial and lateral motor cell columns of lamina IX were associated with among the highest levels of NT-4/5 cRNA hybridization in the spinal cord gray matter (Fig. $1 A$; see Fig. $6 A$ ). Lower, but significant, levels of autoradiographic labeling of NT-4/5 mRNA were also observed in a subpopulation of white matter glia in the dorsal, ventral, and lateral funiculi (Fig. $1 A$; see Figs. $8 A, 9 A$ ).

Contrasting NT-4/5, autoradiographic labeling of BDNF mRNA was restricted to the gray matter of the normal adult rat spinal cord, with little or no significant hybridization observed in the white matter (Fig. $2 A$; see Figs. $8 C, 9 E$ ). Within the gray matter, BDNF mRNA labeling was most dense in association with the $\alpha$ motoneurons of the lamina IX, including both the medial and lateral motor cell columns (Fig. 2A; see Fig. 6C). By comparison, lower levels of BDNF cRNA hybridization were observed elsewhere in the cord, including the remaining laminae of the ventral horn (Fig. $2 A$ ), in the dorsal horn (see Fig. 7D), and in the spinal cord white matter (see Figs. $8 C, 9 E$ ).

NT-3 cRNA hybridization was dense in medial and lateral $\alpha$ motoneurons of lamina IX, and in sparsely distributed neurons throughout the remainder of the ventral and dorsal horns (Fig. $3 A$; see Fig. $7 E$ ). The level of NT-3 mRNA labeling associated with spinal cord motoneurons closely resembled that of BDNF, both being less dense than the level of NT-4/5 mRNA labeling associated with motoneurons in adjacent sections (see Fig. 6E). In addition to producing less dense hybridization relative to $\mathrm{NT}-4 / 5$, the BDNF and NT-3 riboprobes also labeled relatively fewer $\alpha$ motoneurons (compare Figs. $1 A, 2 A, 3 A$ ). Additionally, the NT-3 riboprobe produced dense autoradiographic label in association with some white matter glia, but by comparison with the NT-4/5 riboprobe, labeled fewer cells (see Fig. 9B).

Levels of BDNF, NT-3, and NT-4/5 mRNA labeling in the spinal cord white matter and in the dorsal and ventral horns, were quantified by determination of the ROD from scanned film autoradiographs. This analysis showed that NT-4/5 mRNA labeling 

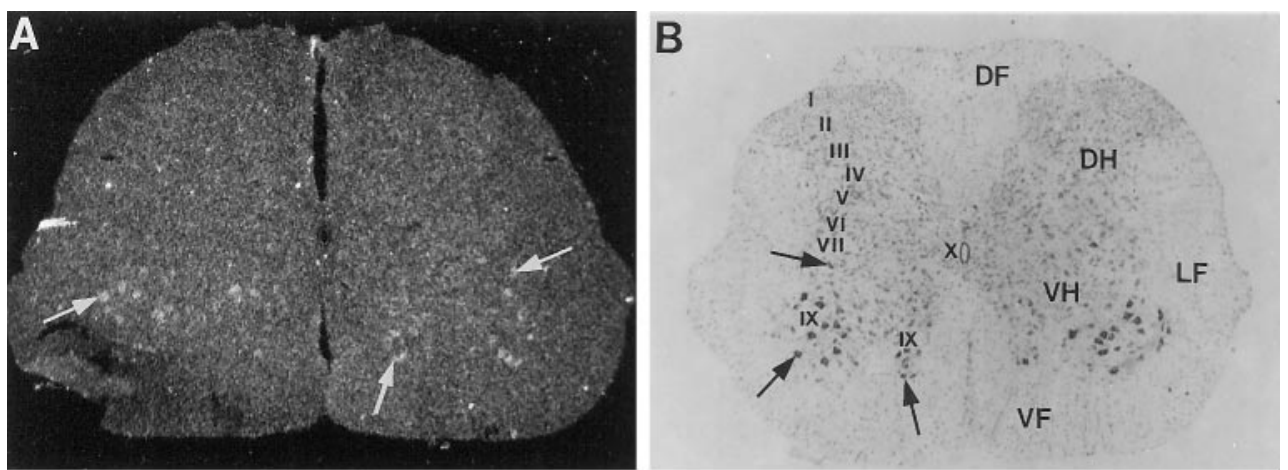

Figure 2. BDNF mRNA expression was dense in association with the $\alpha$ motoneurons of the adult rat lumbosacral spinal cord and upregulated therein by systemic KA. Dark-field photomicrographs show the autoradiographic localization of hybridization to BDNF mRNA in representative transverse sections through the lumbar region of the spinal cord of a control rat $(A)$, and in parallel sections of paired experimental rats at $4(C), 24(D), 72(E)$, or $168 \mathrm{hr}(F)$, after intraperitoneal administration of KA. Bright-field photomicrograph $(B)$ shows the appearance of Nisslstained cellular elements in the dorsal $(D F)$, lateral $(L F)$, and ventral funiculi $(V F)$ of the white matter, and in laminae I-X of the gray matter, in a parallel section from a control animal. There was an increase in density of autoradiographic grains overlying the motoneurons of lamina IX of the ventral horn of the spinal cord at $72 \mathrm{hr}(E)$, after kainic acid administration relative to control $(A)$ (Fig. 5). Arrows indicate position of lamina IX motoneurons. $\mathrm{DH}$, Dorsal horn; $V H$, ventral horn. Scale bar, $500 \mu \mathrm{m}$.
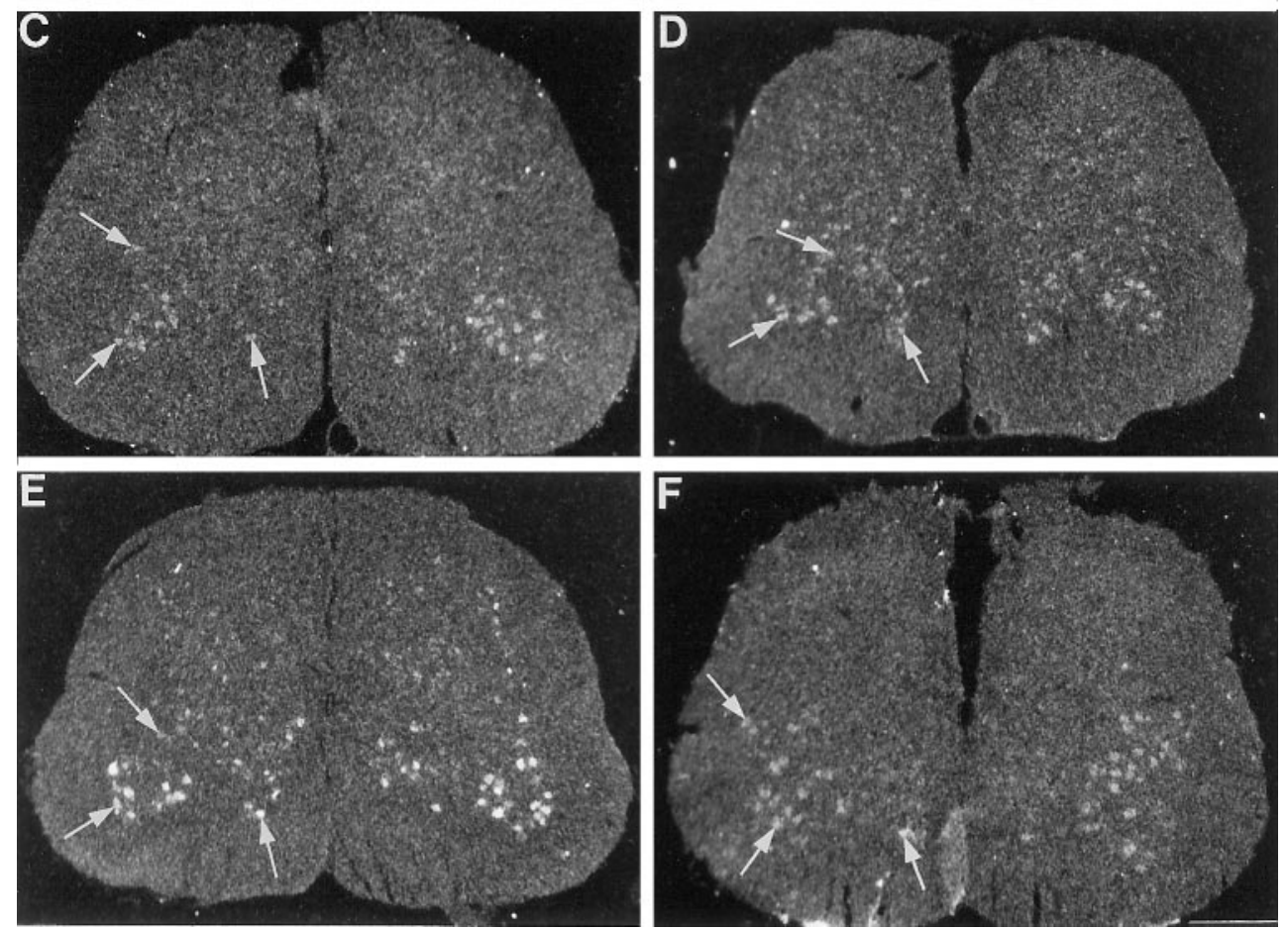

in the normal adult rat lumbosacral spinal cord was 3.5-fold higher in the dorsal and ventral horns, relative to the white matter (Fig. 4). By contrast, overall levels of BDNF and NT-3 mRNA labeling were similar throughout the cord, but were elevated by $\sim 1.2$-fold in the spinal cord gray matter relative to the white matter. No autoradiographic signal above background was obtained in the spinal cord white or gray matter after hybridization to the BDNF, NT-3, or NT-4/5 sense strand control riboprobes (see Fig. $6 H$ ).

\section{Spatiotemporal alterations in neurotrophin gene expression in response to systemic KA}

NT-4/5 mRNA labeling was dramatically upregulated by systemic $\mathrm{KA}$ in a region-specific and biphasic manner (Figs. 1, 5A). The first and most robust changes in NT-4/5 cRNA hybridization were observed at $4 \mathrm{hr}$ after KA injection. At this time point, significant increases in NT-4/5 mRNA labeling were observed in the spinal cord white matter $(p<0.01)$ and in the dorsal horn $(p<0.05)$, throughout the length of the lumbar enlargement (Figs. $1 C, 5 A$; see Figs. $7 B, 8 B$ ). The most dramatic upregulation in NT-4/5 mRNA labeling in the dorsal horn was observed in laminae I and II, which had previously been associated with the lowest levels of NT-4/5 mRNA hybridization. Increases in NT-4/5 cRNA hybridization in laminae III-VII were also readily apparent (Fig. $1 C$; see Fig. $7 B)$. At the $4 \mathrm{hr}$ time point, there was an $\sim 3.5$-fold increase in NT-4/5 mRNA labeling in the white matter $(p<0.01)$ and a 2.6-fold increase in the dorsal horn of the spinal cord gray matter $(p<0.05)$, compared with control sections processed in parallel (Fig. $5 A$ ). In the ventral horn of the spinal cord, there was a trend toward similar increases in NT-4/5 mRNA labeling at the same time point, but these changes did not reach statistical significance. By contrast to the robust changes observed in NT-4/5 mRNA labeling at $4 \mathrm{hr}$ after $\mathrm{KA}$ injection, at the same time point, there was little change in the density of BDNF or NT-3 mRNA labeling in each region of the spinal cord examined (Figs. $2 C$, $3 C, 5 B, C)$.

After the initial dramatic increase in NT-4/5 mRNA labeling at $4 \mathrm{hr}$ after systemic KA, levels of NT-4/5 cRNA hybridization were similar to control values at the $24 \mathrm{hr}$ time point (Figs. $1 D$, $5 A$ ). By $72 \mathrm{hr}$ however, NT-4/5 cRNA hybridization in the dorsal horn was, for the second time, significantly elevated over controls $(p<0.5)$ (Fig. 1E). NT-4/5 mRNA labeling in the dorsal horn was also elevated over controls when examined at $168 \mathrm{hr}$ after KA injection, when levels of hybridization were increased by threefold $(p<0.01)$ (Figs. $1 F, 5 A$; see Fig. $7 C$ ). KA-induced changes in NT-4/5 mRNA labeling in the ventral horn were not statistically significant at any of the time points examined (Figs. 5A, 6B). 

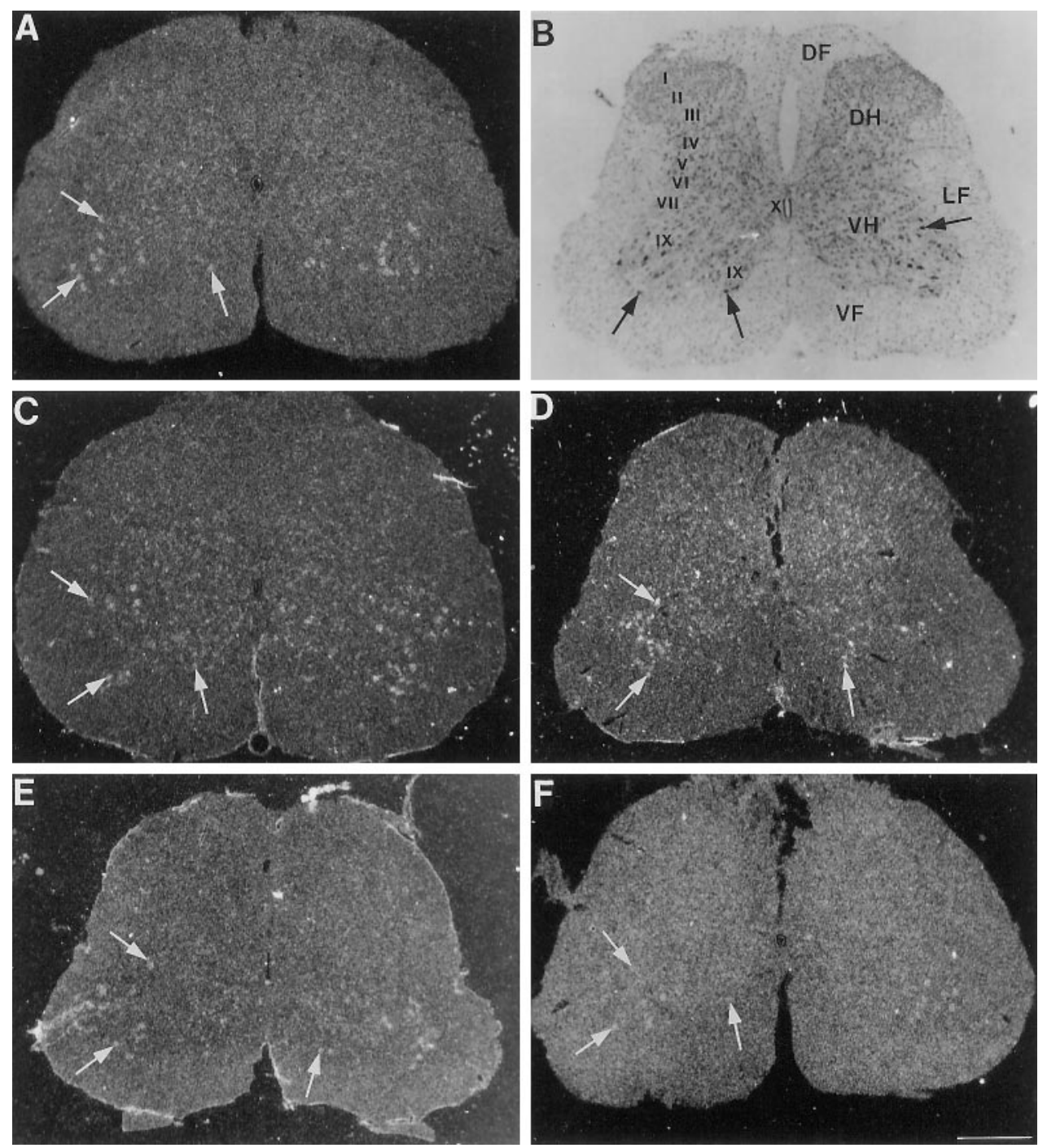

Figure 3. NT-3 mRNA expression was dense in association with the $\alpha$ motoneurons of the adult rat lumbosacral spinal cord, and unchanged by systemic KA. Dark-field photomicrographs show the autoradiographic localization of hybridization to NT-3 mRNA in representative transverse sections at the $\mathrm{L} 3 / \mathrm{L} 4$ level of the spinal cord of a control rat $(A)$, and in parallel sections of paired experimental rats at $4(C), 24(D), 72(E)$, or $168 \mathrm{hr}(F)$, after intraperitoneal administration of KA. Bright-field photomicrograph (B) shows the appearance of Nissl-stained cellular elements in the dorsal $(D F)$, lateral $(L F)$, and ventral funiculi $(V F)$ of the white matter, and in laminae I-X of the gray matter, in a parallel section from a control animal. Arrows indicate position of lamina IX motoneurons. $D H$, Dorsal horn; $V H$, ventral horn. Scale bar, $500 \mu \mathrm{m}$.
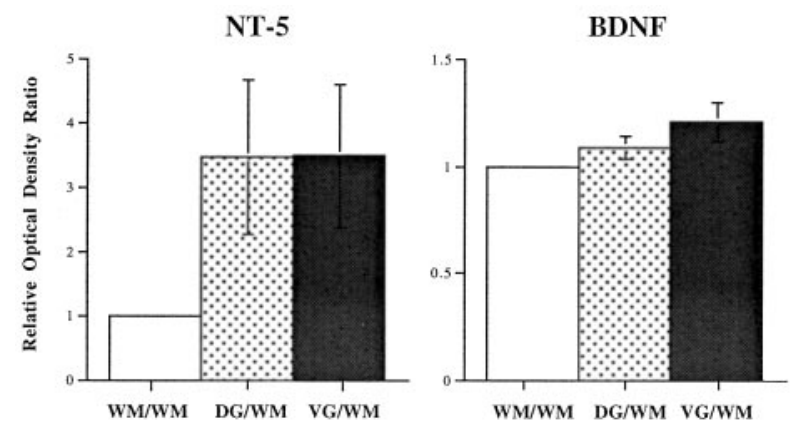

WM/WM DG/WM VG/WM

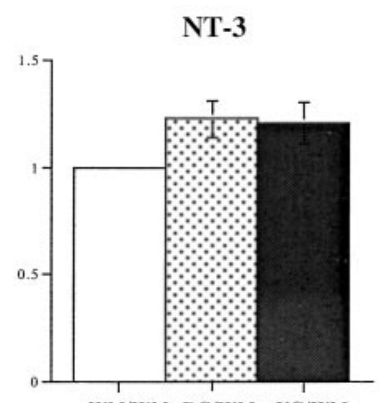

WM/WM DG/WM VG/WM

Figure 4. Quantification of the relative abundance of NT-4/5, BDNF, and NT-3 mRNA labeling in the dorsal and ventral regions of the spinal cord gray matter, compared with the white matter, in the normal adult rat lumbosacral spinal cord. The values plotted represent the ratio of the mean \pm SE of the relative optical density, measured from film autoradiographs, of the $\left[{ }^{35} \mathrm{~S}\right]$-labeled riboprobes in the each region of the control spinal cord examined, that is the white matter $(W M)$, dorsal gray matter $(D G)$, or ventral gray matter $(V G)$, compared with the white matter $(n=6)$. NT-4/5 mRNA labeling was 3.5-fold higher in the dorsal and ventral horns of the spinal cord gray matter relative to the white matter of the normal adult spinal cord. Compared with NT-4/5, BDNF and NT-3 mRNA labeling was more evenly distributed across the white and gray layers of the spinal cord, but each was elevated by $\sim 1.2$-fold in the gray relative to the white matter of the normal adult rat.

Systemic administration of KA produced significant changes in BDNF mRNA labeling in the ventral horn of the spinal cord at 72 hr, when the level of BDNF cRNA hybridization was elevated by 2.6-fold relative to control tissue processed in parallel $(p<0.01)$ (Figs. $2 E, 5 B, 6 D)$. Elevated levels of BDNF mRNA labeling were observed in association with neurons in all laminae of the ventral horn, including the motoneurons of the medial and lateral motor cell columns of lamina IX. Significant changes in BDNF
cRNA hybridization were not observed in the dorsal horn or in the spinal cord white matter at the same time points (Figs. 2, 5B).

By contrast to the changes observed in the relative amount of hybridization of both the NT-4/5 and BDNF cRNA probes after KA exposure, significant changes were not observed in NT-3 cRNA hybridization in any region of the spinal cord, at any of the time points examined (Figs. 3, 5C).

Histological damage within the lumbosacral spinal cord, such 

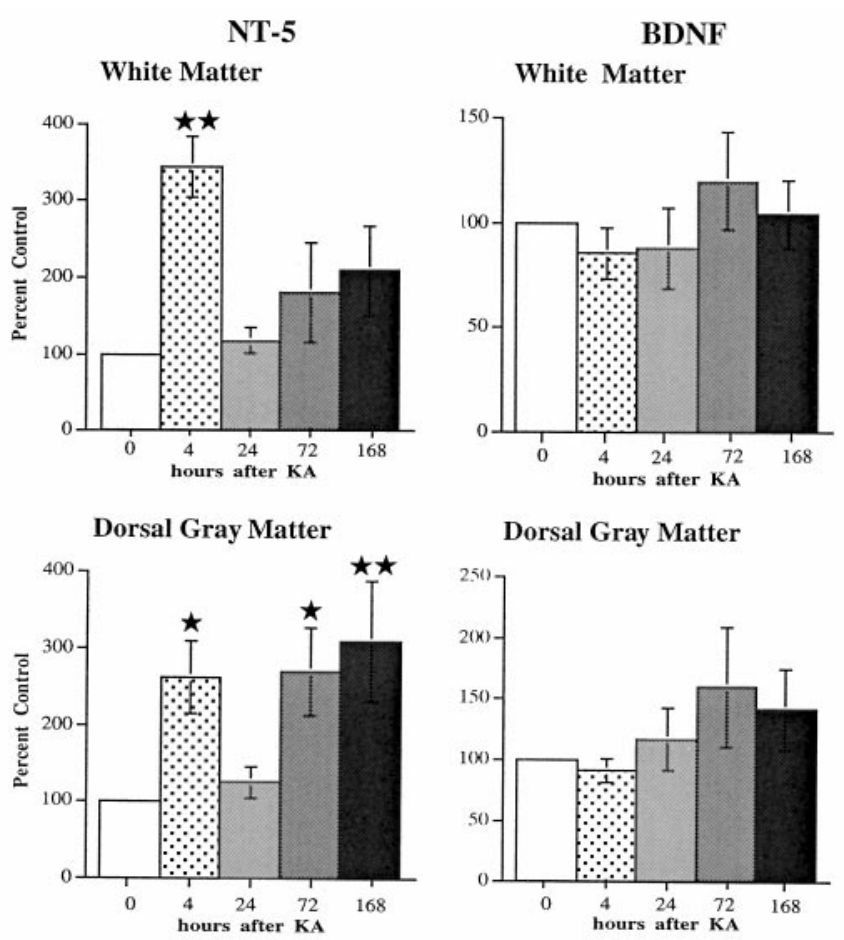

Figure 5. Quantification of kainic acidinduced changes in the expression of NT-4/5, BDNF, and NT-3 mRNAs in the white and gray matter of the adult rat lumbosacral spinal cord. Bar graphs show densitometric measurements of film autoradiograms of $(A) \alpha-\left[{ }^{35} \mathrm{~S}\right]-\mathrm{NT}$ 4/5 cRNA labeling, $(B) \alpha-\left[{ }^{35} \mathrm{~S}\right]-\mathrm{BDNF}$ cRNA labeling, or $(C) \alpha-\left[{ }^{35} \mathrm{~S}\right]-\mathrm{NT}-3$ cRNA labeling in the white matter, and in the dorsal or ventral gray regions, of the spinal cord of rats who were killed at 4, 24, 72, or $168 \mathrm{hr}$ after intraperitoneal injection of KA. Measurements in each region from KA-treated animals were expressed as a percentage of values from paired control animals. The values plotted represent group mean \pm SE. NT-4/5 $(n=4,4 \mathrm{hr} ; n=6,24 \mathrm{hr} ; n=3,72$ and $168 \mathrm{hr}), B D N F(n=4,4 \mathrm{hr} ; n=5,24 \mathrm{hr}$; $n=3,72$ and $168 \mathrm{hr})$, and NT-3 $(n=5$, $4 \mathrm{hr} ; n=7,24 \mathrm{hr} ; n=3,72$ and $168 \mathrm{hr}$ ). Significant differences in mRNA labeling between treated and control groups were shown by ANOVA $(p<0.01)$. Stars indicate significant differences from control values $(\star p<0.05 ; \star \star p<0.01$; StudentNewman-Keuls post hoc test).

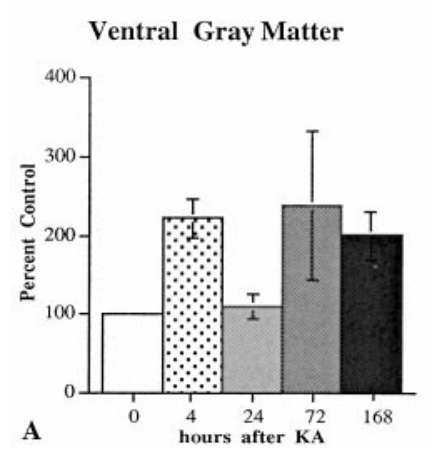

Dorsal Gray Matter

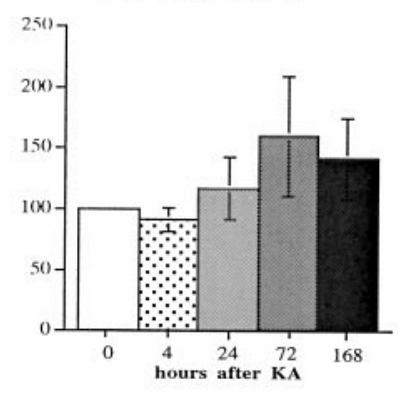

Ventral Gray Matter

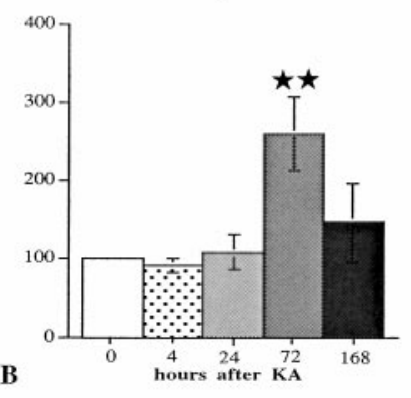

NT-3

White Matter

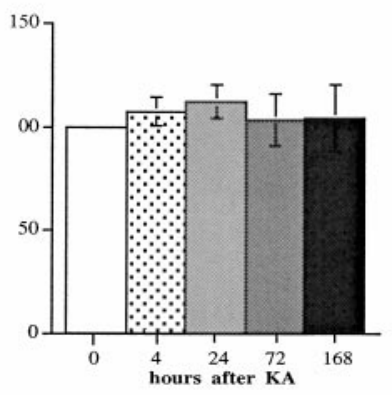

Dorsal Gray Matter

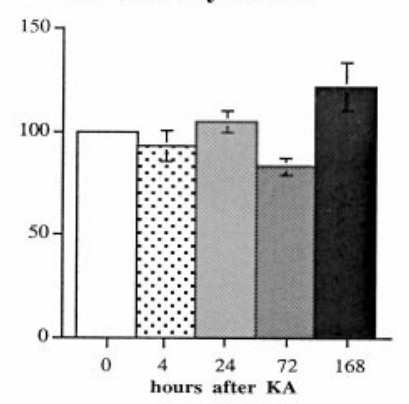

Ventral Gray Matter

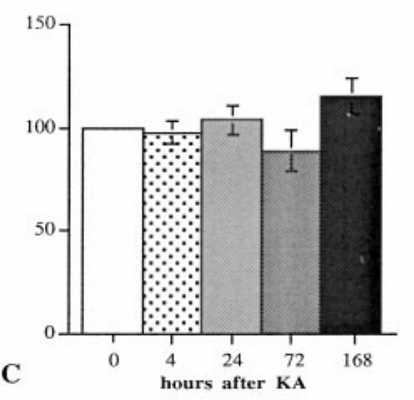

as dark and shrunken cells or obvious loss of lamina IX neurons, was not obvious at any of the time points examined after systemic KA administration. A quantitative assessment of cord area (Table 1), $\alpha$ motoneuron number, and $\alpha$ motoneuron diameter (Table 2) in the L3/L4 segments of the spinal cord indicated no statistical differences by one-way ANOVA in the KA-treated animals compared with controls.

\section{Expression of neurotrophins by spinal cord glia}

Glia in the spinal cord white matter were associated with significant levels of autoradiographic label after hybridization to either the NT-4/5 or NT-3 cRNA probes (Figs. 1, 7, $8 A, 9 A, B$ ). Both the relative number and distribution of labeled glia was greatest with the NT-4/5 riboprobe. There was a dramatic increase in both the density of NT-4/5 mRNA labeling associated with white matter glia at $4 \mathrm{hr}$ after systemic administration of $\mathrm{KA}$, and in the relative number of labeled glia (Figs. 1, 5A, 8B). Increases in NT-4/5 mRNA hybridization were observed throughout the white matter, but were most pronounced in dorsal funiculi (Fig. $1 C$, $8 B$ ). Similar changes in NT-3 mRNA labeling in white matter glia after KA administration were not observed (Fig. 5, compare $A$, $C)$. In the normal cord, NT-4/5-producing white matter glia closely resembled the distribution of $2^{\prime}, 3^{\prime}$-cyclic nucleotide $3^{\prime}$ - phosphodiesterase (CNPase)-positive oligodendrocytes in parallel sections (Scarisbrick et al., 1997), and there was virtually complete colocalization of white matter glia positive for DIGlabeled NT-4/5 cRNA and the oligodendrocyte marker Rip (Fig. $9 C, D)$.

NT-4/5 cRNA hybridization in the spinal cord gray matter of control animals was primarily associated with neurons, but significant levels of autoradiographic label were also associated with smaller cellular elements, with darkly stained nuclei, likely to be glia. Significant levels of NT-3 cRNA hybridization were also associated with gray matter glia, but the number of labeled cells was much less than that observed after NT-4/5 cRNA hybridization (Fig. 6A, E).

\section{DISCUSSION}

Because neurotrophins have been used to treat motoneuron diseases [BDNF Study Group (Phase III), 1999], studies of their in vivo expression patterns and regulation in the adult spinal cord are critical to understanding possible mechanisms, and efficacy, of potential treatment strategies. We show that NT-4/5 is robustly expressed by neurons throughout the gray matter of the normal adult rat cord, and by a subpopulation of white and gray matter 

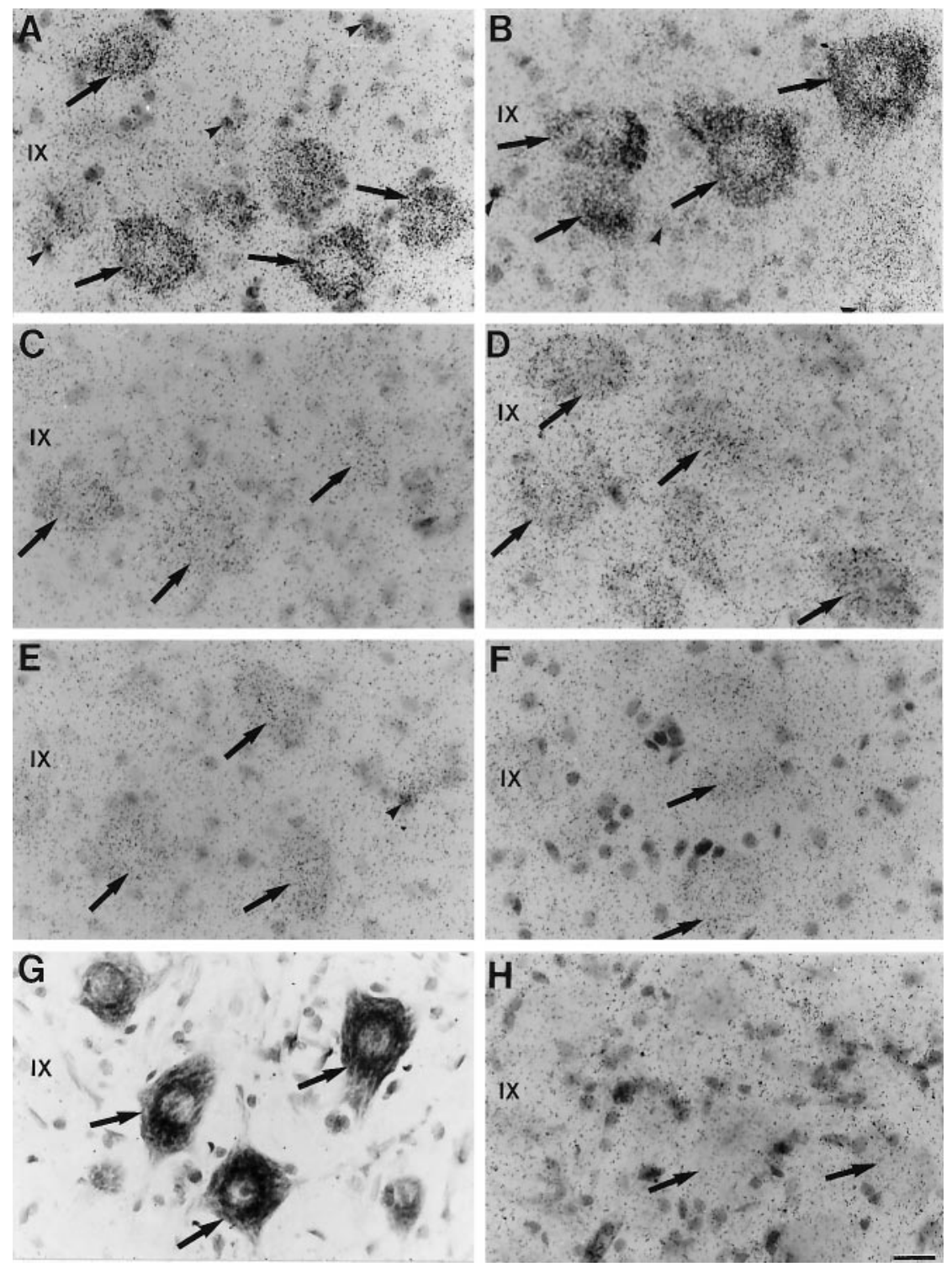

Figure 6. NT-4/5, BDNF, and NT-3 mRNA expression was dense in the lumbosacral $\alpha$ motoneurons of lamina IX, but only BDNF mRNA levels were significantly altered by systemic KA. Bright-field photomicrographs show the autoradiographic localization of hybridization to NT-4/5 $(A, B)$, BDNF $(C, D)$, and NT-3 $(E, F)$ mRNAs within lamina IX of the ventral horn of control animals $(A, C, E)$ and paired experimental animals that were killed at $72 \mathrm{hr}$ after KA administration $(B, D, F)$. Although the level of NT-4/5 and NT-3 mRNA hybridization in the ventral horn was unchanged after KA administration, the level of BDNF mRNA hybridization was elevated by 2.6 -fold at the $72 \mathrm{hr}$ time point $(p<0.01$; Fig. 5). In addition to dense autoradiographic signal in association with the $\alpha$ motoneurons of lamina IX (arrows), the NT-4/5, and to a lesser extent the NT-3, riboprobe produced significant levels of signal in association with gray matter glia ( $A, B, E$, arrowheads). $G$ shows the appearance of $\alpha$ motoneurons in a Nissl-stained section from a control animal, and $H$ shows the typical background level of autoradiographic signal produced by the ${ }^{35} \mathrm{~S}$-labeledNT- $4 / 5$ sense stand cRNA (arrows indicate $\alpha$ motoneurons). Scale bar, $25 \mu \mathrm{m}$.

\begin{tabular}{|c|c|c|c|c|}
\hline Treatment & $n$ & $\begin{array}{l}\text { Spinal cord area } \\
(\text { mean } \pm \mathrm{SEM}) \\
\mathrm{mm}^{2}\end{array}$ & $\begin{array}{l}\text { Gray matter area } \\
\text { (mean } \pm \text { SEM) } \\
\mathrm{mm}^{2}\end{array}$ & $\begin{array}{l}\text { White matter area } \\
(\text { mean } \pm \text { SEM }) \\
\mathrm{mm}^{2}\end{array}$ \\
\hline Control & 7 & $6.24 \pm 0.187$ & $3.21 \pm 0.131$ & $2.96 \pm 0.105$ \\
\hline $4 \mathrm{hr}$ & 5 & $6.07 \pm 0.166$ & $3.07 \pm 0.077$ & $3.03 \pm 0.106$ \\
\hline $24 \mathrm{hr}$ & 5 & $5.95 \pm 0.155$ & $3.00 \pm 0.019$ & $2.86 \pm 0.094$ \\
\hline $72 \mathrm{hr}$ & 8 & $6.31 \pm 0.079$ & $3.44 \pm 0.024$ & $2.79 \pm 0.106$ \\
\hline $168 \mathrm{hr}$ & 5 & $6.56 \pm 0.249$ & $3.28 \pm 0.247$ & $3.27 \pm 0.147$ \\
\hline
\end{tabular}

Mean area $\left(\mathrm{mm}^{2}\right)$ of the total cord, the cord gray matter, or the cord white matter, in the L3/L4 segments of rats from control or KA-treated animals ( \pm SEM).

$n=$ number of animals at each indicated time point. One-way ANOVA showed no significant differences, in any of the measurements, among the different treatment groups.

glia. BDNF and NT-3 mRNAs were also expressed by $\alpha$ motoneurons, but elsewhere exhibited a more restricted expression pattern. Within the motoneuron pools of the lumbosacral cord, both overlapping and distinct domains of neurotrophin expression were observed, supporting the idea that neurotrophins act in a complementary and/or compensatory fashion. Taken with the temporally and spatially distinct changes in NT-4/5 and BDNF expression observed after systemic KA, data described herein support the hypothesis that neurotrophins play multifactorial roles in the normal cord and in the response of the cord to excitotoxic stimuli.

\section{Potential responsive neurons}

Expression of BDNF, NT-3, and NT-4/5 by cord neurons, particularly, the $\alpha$ motoneurons of laminae IX, indicates that each factor may be available to responsive neurons by autocrine or paracrine mechanisms, in addition to retrograde means of availability. Spinal cord motoneurons are responsive to BDNF, NT-3, and NT-4/5 (Henderson et al., 1993; Wong et al., 1993; Kaal et al., 1997), and express high-affinity TrkB and TrkC receptors, through which these factors exert their biological effects (Frisen et al., 1992; Merlio et al., 1992; Funakoshi et al., 1993). The traditional view of neurotrophin action is production by, and derivation from, target tissues by retrograde axon transport, to affect neuron viability, growth, and biosynthetic activities (Thoenen, 1991). The emerging view is that neurotrophins addi- 
Table 2. Comparison of $\alpha$ motoneuron number and diameter in control and KA-treated animals

\begin{tabular}{llcll} 
& $\begin{array}{l}\text { Motoneuron } \\
\text { number/section } \\
(\text { mean } \pm \text { SEM })\end{array}$ & $\begin{array}{l}\text { Motoneuron area } \\
\left(\mu \mathrm{m}^{2}\right)(\text { mean } \pm \text { SEM })\end{array}$ & $\begin{array}{l}\text { Maximum } \\
\text { diameter }(\mu \mathrm{m}) \\
(\mathrm{mean} \pm \mathrm{SEM})\end{array}$ \\
\hline Treatment & $n$ & $9.95 \pm 0.54$ & $1448.99 \pm 111.85$ & $\begin{array}{l}\text { Minimum } \\
\text { diameter }(\mu \mathrm{m}) \\
(\mathrm{mean} \pm \mathrm{SEM})\end{array}$ \\
$168 \mathrm{hr}$ & 6 & $10.29 \pm 0.52$ & $1618.62 \pm 147.41$ & $54.03 \pm 1.82$ \\
& 5 & & $56.99 \pm 2.53$
\end{tabular}

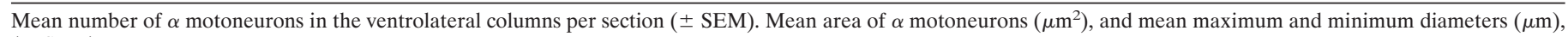
( \pm SEM).

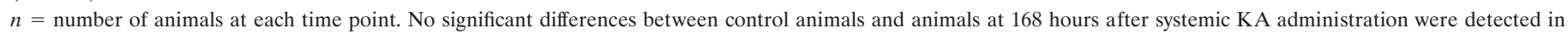
any of the measurements using one-way ANOVA.

Figure 7. NT-4/5 mRNA expression was dense in the dorsal horn of the lumbosacral spinal cord and upregulated by systemic KA. Bright-field photomicrographs show the autoradiographic localization of hybridization of NT-4/5 $(A), \operatorname{BDNF}(D)$ and NT-3 $(E)$ mRNAs within laminae I-IV of the dorsal horn of control animals (arrows). The amount of NT-4/5 mRNA hybridization was significantly elevated at $4(B), 72$ (Fig. $1 E$ ), and $168 \mathrm{hr}$ $(C)$ after KA administration. The level of BDNF and NT-3 mRNA hybridization in the dorsal horn was unchanged at each time point examined after KA administration (arrowheads show examples of labeled cells) (see Fig. 5 for quantification). Brightfield photomicrograph $(F)$, shows the appearance of Nissl-stained cellular elements in lamina I-IV of the dorsal horn in a parallel section from a control animal. Scale bar, $25 \mu \mathrm{m}$.
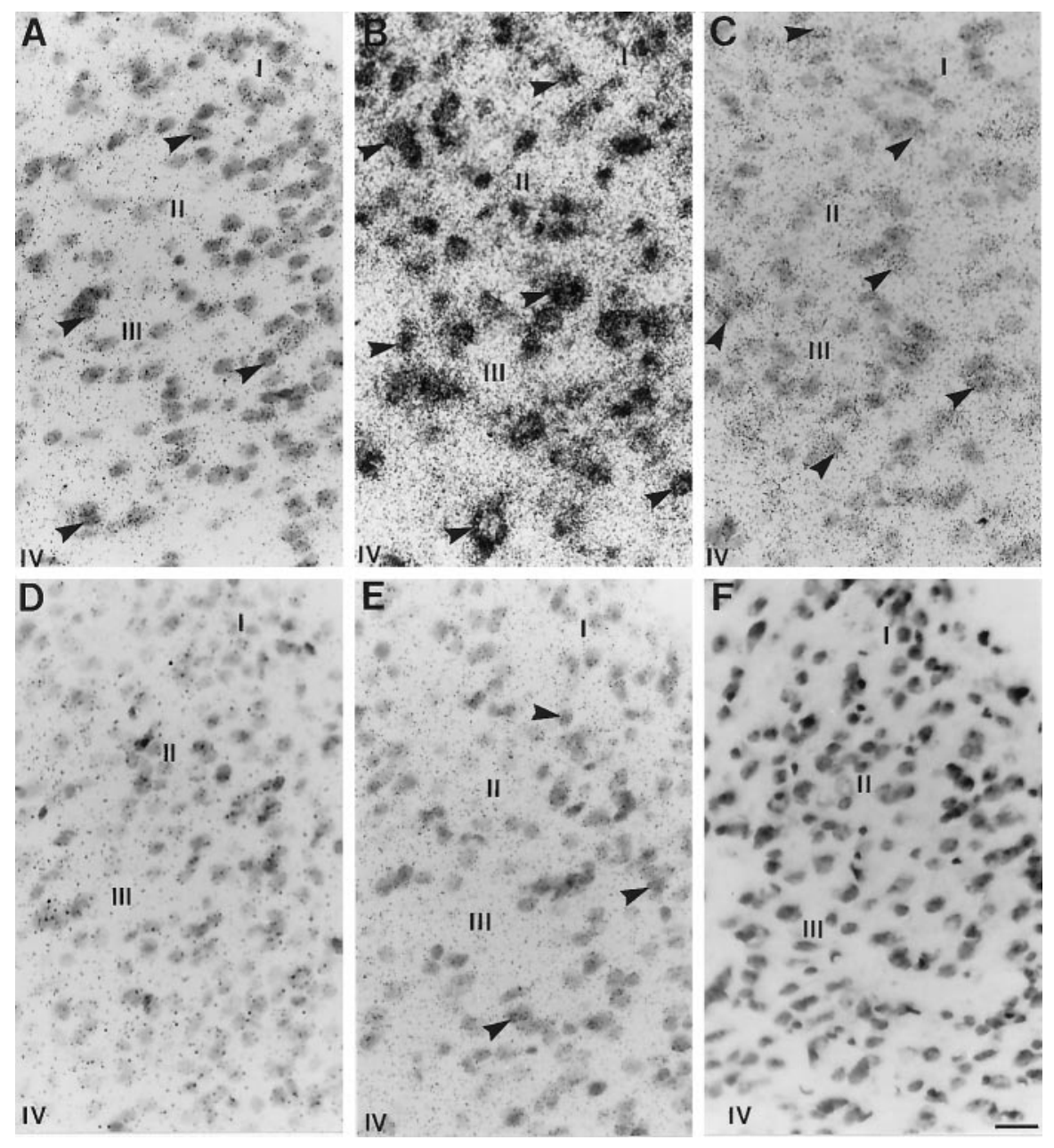

tionally function locally, whereby they are produced by, or in, the immediate vicinity of responsive neurons, and signal by autocrine or paracrine mechanisms (Ernfors et al., 1992; Schecterson and Bothwell, 1992). The present findings, demonstrating that $\alpha$ motoneurons produce mRNA encoding each of these growth factors, further supports the concept of local neurotrophin synthesis and action.

The abundance of BDNF, NT-3, and NT- $4 / 5$ expression by $\alpha$ motoneurons and NT-3 and NT-4/5 throughout all regions of spinal cord gray matter, supports the possibility that these factors provide trophic support to responsive descending or primary afferent neurons. It is established that subsets of dorsal root ganglion neurons are responsive to BDNF, NT-3, and/or NT-4/5 (for review, see Snider, 1994). Also, these neurotrophins support CNS neurons that project to the cord, including Red nucleus
(Diener and Bregman, 1994; Liu et al., 1999) and corticospinal neurons (Schnell et al., 1994; Giehl and Tetzlaff, 1996; Junger and Varon, 1997). Moreover, after adult rat spinal cord hemisection, neurotrophin administration increases the extent of serotonergic, noradrenergic, and corticospinal axon growth into transplanted fetal cord tissue (Bregman et al., 1997).

\section{Regulation of neurotrophins by systemic KA}

Temporally distinct changes observed in BDNF and NT-4/5 expression after KA administration emphasize the importance of these factors in acute and delayed, secondary responses of the cord to activity and injury-related events. It is possible that acute increases in NT-4/5 expression at $4 \mathrm{hr}$ in the spinal cord white matter and dorsal horn were the direct result of activation of $\mathrm{KA} / \mathrm{AMPA}$ receptors, that is upregulation in response to in- 

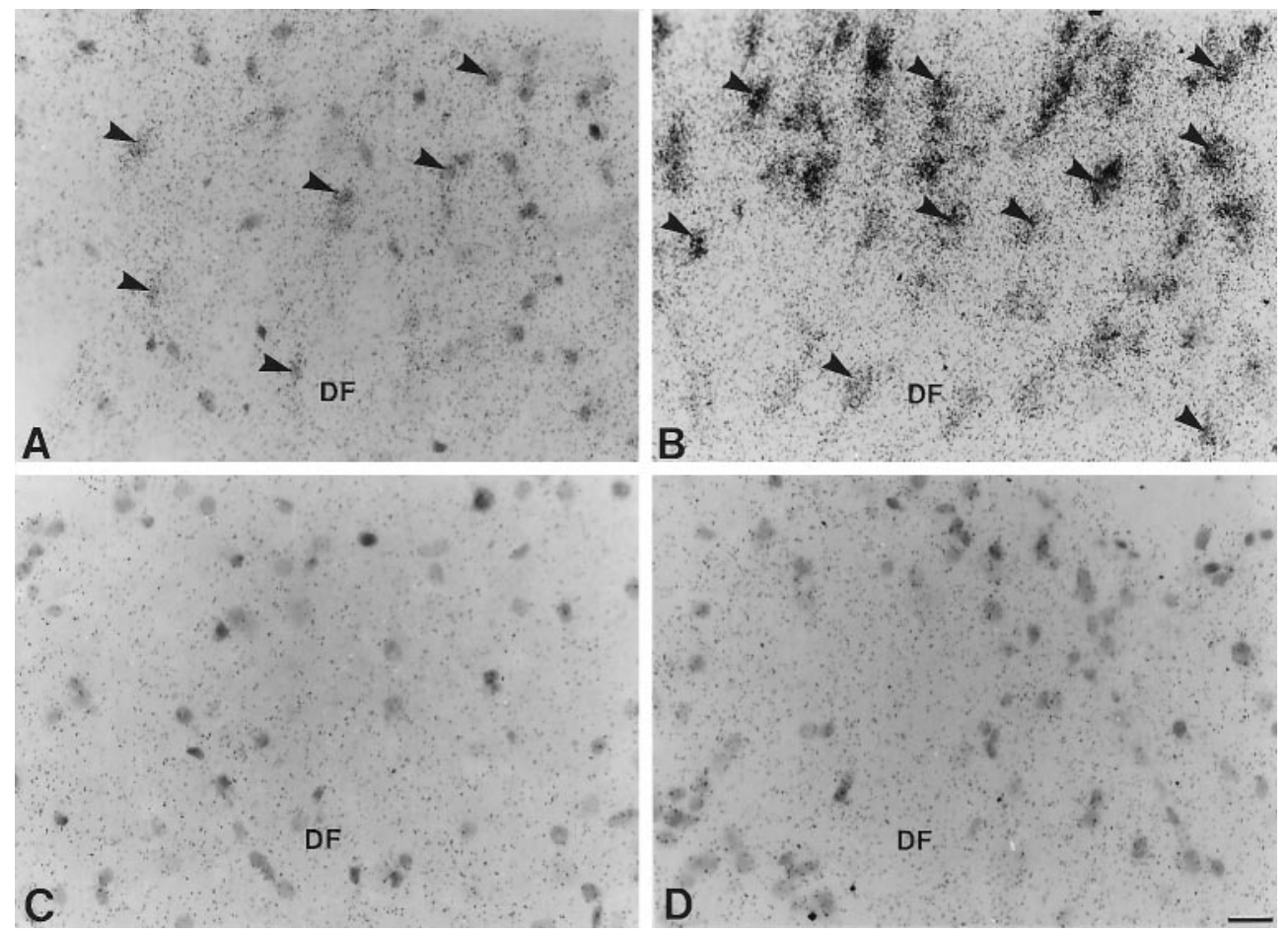

Figure 8. High levels of NT-4/5 mRNA expression were associated with glia of the dorsal funiculus of the lumbosacral spinal cord white matter, and the level of hybridization was dramatically upregulated by systemic KA. Bright-field photomicrographs show the autoradiographic localization of hybridization to NT-4/5 mRNA within the dorsal funiculus of the adult rat spinal cord of a control rat $(A)$, and of a paired experimental rat that was killed at $4 \mathrm{hr}(B)$ after kainic acid administration (arrowheads show examples of labeled cells). A significant elevation in the level of NT-4/5 cRNA hybridization was observed in the spinal cord white matter at $4 \mathrm{hr}(B)$ after systemic KA administration (Fig. 5). In contrast, significantly lower levels of hybridization were produced by the $\operatorname{BDNF}(C)$ and NT-3 $(D)$ riboprobes in association with glia of the dorsal funiculus of control animals, and this level was not altered after exposure to KA (Figs. 2, 3). Scale bar, $25 \mu \mathrm{m}$.
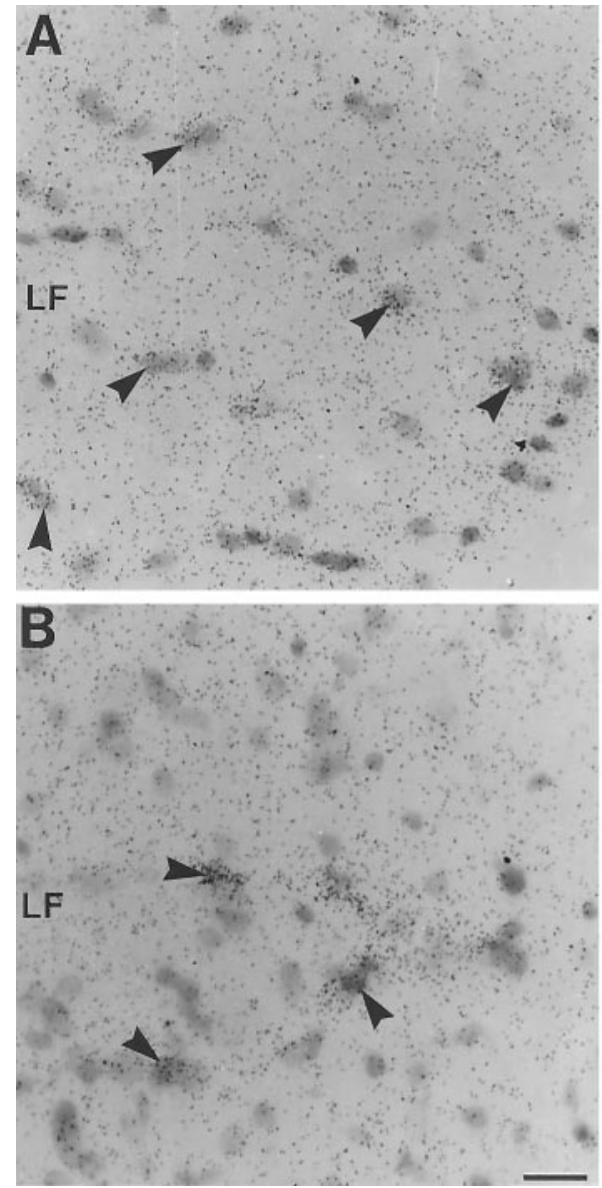
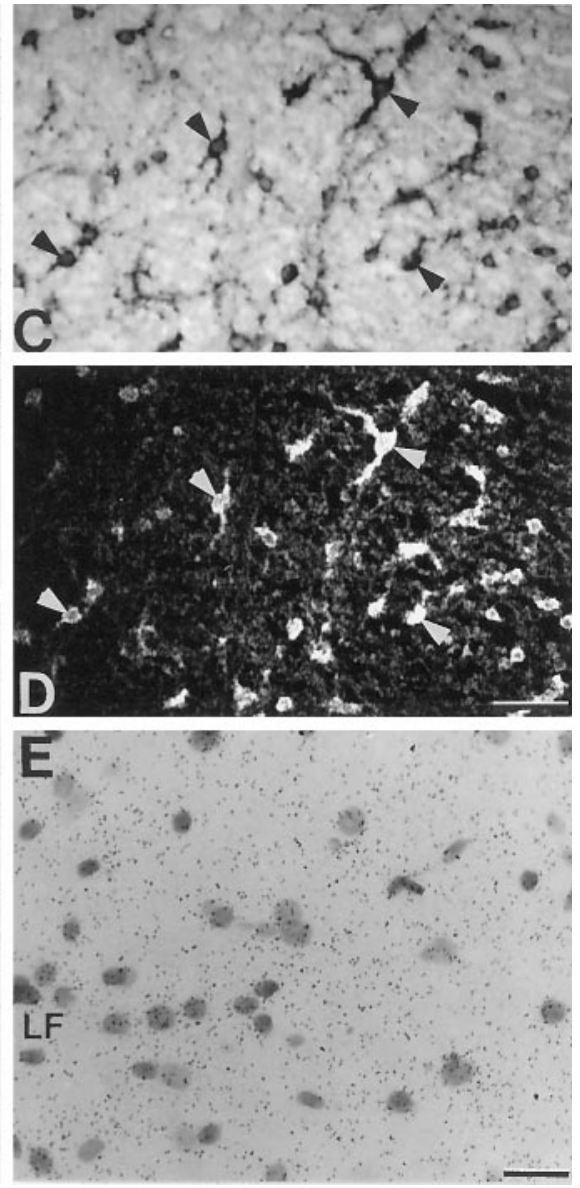

Figure 9. Significant levels of NT-4/5 and NT-3 mRNA expression were associated with glia of the lateral funiculi of the normal adult rat lumbosacral spinal cord white matter. Bright-field photomicrographs show the autoradiographic localization of hybridization produced by the NT-4/5 $(A)$, NT-3 $(B)$, and BDNF $(E){ }^{35}$ S-labeled riboprobes in the lateral funiculus of control rats (arrowheads show examples of labeled cells). Virtually all cells in the lateral funiculus of the normal spinal cord white matter were double-labeled (examples at arrowheads), for DIG-labeled NT-4/5 cRNA $(C)$ and immunofluorescence for the oligodendrocyte marker Rip $(D)$. Scale bars: $A, B, E, 25 \mu \mathrm{m} ; C, D, 50 \mu \mathrm{m}$. 
creased cellular activity. Later increases, observed in the gray matter at 72 and $168 \mathrm{hr}$ for NT-4/5, and at $72 \mathrm{hr}$ for BDNF, may have been associated with delayed, secondary, cellular responses to excess KA, downstream of the initial increase in activity. Although both BDNF and NT-4/5 ligands signal through the TrkB receptor, the different spatial and temporal changes observed in their expression after systemic KA administration suggests they are differentially regulated by KA-receptor stimulation, and that each serves partially distinct roles in the response of the cord to excitotoxic stimuli.

There is a large literature concerning the influence of neural activity and seizures on neurotrophin expression in the adult brain. Systemic kainic acid-induced (Gall et al., 1991; Isackson et al., 1991a; Dugich-Djordjevic et al., 1992; Gall, 1992) or kindlinginduced (Ernfors et al., 1991; Bengzon et al., 1993) seizures increase NGF and BDNF and decrease NT-3 mRNAs in the rodent hippocampus. In contrast to the robust expression of NT-4/5 mRNA in the adult rat cord in the hippocampus, NT-4/5 mRNA is expressed at very low levels and has not been shown to be regulated by activity (Isackson, 1995; Binder et al., 1999). Peripheral nerve crush or axotomy do result in increased expression of p75-NGFR (Koliatsos et al., 1991), TrkB, and TrkC in spinal motoneurons (Funakoshi et al., 1993; Piehl et al., 1994). In muscle, the level of neurotrophin expression is differentially regulated by activity, such that sciatic nerve transection produces increases in TrkB and BDNF, decreases in NT-4/5, but no change in NT-3, whereas electrical stimulation produces increases in NT-4/5 and decreases in NT-3 and BDNF (Funakoshi et al., 1993, 1995). These studies, using in vitro methods, did not report significant changes in neurotrophin expression within the spinal cord. This is the first report to directly examine the cellular localization of neurotrophin mRNA in the adult spinal cord and to demonstrate dramatic alterations in expression of NT-4/5 and BDNF therein, in response to systemic administration of the glutamate receptor agonist KA.

\section{Neurotrophins in neuroprotection and plasticity within the adult spinal cord}

Neurotrophins produced within the cord may regulate neuronal survival and biochemical characteristics in addition to synaptic plasticity (Levine et al., 1996; Cabelli et al., 1997), and each may be an integral outcome of KA receptor-mediated upregulation of NT-4/5 and BDNF observed in this study. Whereas results of neurotrophin, or neurotrophin receptor, gene knock-outs indicate that neurotrophins are not essential to motoneuron survival during embryogenesis (Ernfors et al., 1994; Jones et al., 1994; Klein et al., 1994; Conover et al., 1995; Liu et al., 1995; Silos-Santiago et al., 1997), these studies do not rule out the possibility that neurotrophins participate in cell survival, or otherwise, in the response of the adult cord to injury. Importantly, BDNF, NT-3, and NGF have been shown to have neuroprotective effects against excitotoxic death in hippocampal (Aloe, 1987; Shigeno et al., 1991; Cheng and Mattson, 1994) and striatal neurons (Frim et al., 1993), possibly via stabilization of intracellular calcium levels, including calcium entering through ionotropic NMDA and voltage-gated calcium channels (Ghosh et al., 1994). Furthermore, BDNF and NT-4/5 enhance motoneuron differentiation and process outgrowth in vitro and attenuate the morphological and biochemical effects of peripheral nerve transection in the adult (Chiu et al., 1994; Koliatsos et al., 1994; Yan et al., 1994; Friedman et al., 1995; Kishino et al., 1997; Tuszynski et al., 1996). In Xenopus neuron-monocyte cocultures, monocyte-derived NT-
4/5 produces acute and long-term effects on motoneuron synaptic activity (Wang and Poo, 1997). Moreover, in the injured adult rat spinal cord, fibroblast grafts producing NT-3 or BDNF promote axonal ingrowth (McTigue et al., 1998), and both factors have been shown to increase in the adult rat cord after spinal cord crush injury (Hayashi et al., 1997).

Widespread cytopathological alterations, cord, or $\alpha$ motoneuron swelling or shrinkage, or a loss of $\alpha$ motoneurons within the L3/L4 segments of the cord, were not observed up to 1 week after systemic KA administration. These observations agree with those of Schwob et al. (1980), who reported that systemic KA caused extensive neuropathological changes in a number of brain regions from $4 \mathrm{hr}$ to 2 weeks after treatment, but did not produce similar changes in the midbrain, pons, cerebellum, brainstem, or spinal cord. These observations support the idea that increases in neurotrophin mRNA expression in response to systemic KA play a neuroprotective role in the cord, at least in the first week after exposure to an excitotoxic stimulus.

\section{Neurotrophin expression by spinal cord glia}

A striking finding was the dense expression and dramatic upregulation of NT-4/5 by cord glia. In the white matter of the normal cord, the overlap between NT-4/5 cRNA-hybridizing cells and immunoreactivity for the oligodendrocyte marker Rip suggests that NT-4/5 mRNA is produced by oligodendroglia. Determination of whether NT-4/5-expressing glia after KA exposure includes oligodendrocytes, astrocytes, and/or microglia awaits further double-labeling experiments. Previous studies have demonstrated production of neurotrophins and/or their highaffinity receptors in cultures of oligodendrocytes, astrocytes, and microglia (Furukawa et al., 1987; Houlgatte et al., 1989; Hutton et al., 1992; Rudge et al., 1992; Barres et al., 1994; Condorelli et al., 1995; Gilad and Gilad, 1995; Elkabes et al., 1996; Kumar and de Vellis, 1996). TrkB and TrkC mRNAs are localized to glial cells within the adult rat CNS, and TrkB is elevated in the glial scar formed after spinal cord lesion in the adult rat and cat (Frisen et al., 1992, 1993).

Evidence for biological effects of select neurotrophins on oligodendrocytes in vitro and in vivo is compelling. NT-3 alone, or in combination with other growth factors, promotes proliferation of optic nerve-derived O2-A progenitors, and survival of mature oligodendrocytes (Barres et al., 1994; Cohen et al., 1996). Recently, immunostaining for both NT-3 and BDNF have been described in white matter glia of the adult rat cord (Dreyfus et al., 1999). Importantly, NT-3- or BDNF-producing fibroblasts increase myelination of axons and proliferation of oligodendrocyte precursors in the contusion injured adult rat spinal cord (McTigue et al., 1998).

Because AMPA/KA receptors are present in the spinal cord white matter, and expression includes both GFAP-positive astrocytes and oligodendrocytes (Barres et al., 1990; Agrawal and Fehlings, 1997), the upregulation of NT-4/5 observed in glia of the KA-injured cord may have been through direct activation of non-NMDA ionotropic glutamate receptors. Indeed, infusion of KA into the rabbit optic nerve produces profound oligodendrocyte degeneration (Matute et al., 1997; Matute, 1998), and in vitro KA produces receptor-mediated oligodendrocyte death (McDonald et al., 1998). The data presented here indicate that NT-4/5 likely participates in neuronal-glial interactions in the normal adult cord and in response to excitotoxic stimuli, and strongly suggests that further study of this growth factor in relation of spinal cord injury is warranted. 


\section{REFERENCES}

Agrawal SK, Fehlings MG (1997) Role of NMDA and non-NMDA ionotropic glutamate receptors in traumatic spinal cord axonal injury. J Neurosci 17:1055-1063.

Aloe L (1987) Intracerebral pretreatment with nerve growth factor prevents irreversible brain lesions in neonatal rats injected with ibotenic acid. Biotechnology 5:1085-1086.

Barres BA, Koroshetz WJ, Swartz KJ, Chun LL, Corey DP (1990) Ion channel expression by white matter glia: the O-2A glial progenitor cell. Neuron 4:507-524.

Barres BA, Raff MC, Gaese F, Bartke I, Dechant G, Barde Y-A (1994) A crucial role for neurotrophin-3 in oligodendrocyte development. Nature 367:371-375.

BDNF Study Group (Phase III) (1999) A controlled trial of recombinant methionyl human BDNF in ALS. Neurology 52:1427-1433.

Becker E, Soler RM, Yuste VJ, Gine E, Sanz-Rodriguez C, Egea J, Marin-Zanaca D, Comella JX (1998) Development of survival responses to brain-derived neurotrophic factor, neurotrophin 3 and neurotrophin $4 / 5$, but not nerve growth factor, in cultured motoneurons from chick embryo spinal cord. J Neurosci 18:7903-7911.

Bengzon J, Kokaia Z, Ernfors P, Kokaia M, Leanza G, Nilsson OG, Persson H, Lindvall O (1993) Regulation of neurotrophin and trkA, trkB and trkC tyrosine kinase receptor messenger RNA expression in kindling. Neuroscience 53:433-446.

Binder DK, Routbort MJ, McNamara JO (1999) Immunohistochemical evidence of seizure-induced activation of trk receptors in the mossy fiber pathway of adult rat hippocampus. J Neurosci 19:4616-4626.

Bregman BS, McAtee M, Dai HN, Kuhn PL (1997) Neurotrophic factors increase axonal growth after spinal cord injury and transplantation in the adult rat. Exp Neurol 148:475-494.

Cabelli RJ, Shelton DL, Segal RA, Shatz CJ (1997) Blockade of endogenous ligands of trkB inhibits formation of ocular dominance columns. Neuron 19:63-76.

Carriedo SG, Yin HZ, Weiss JH (1996) Motor neurons are selectively vulnerable to AMPA/kainate receptor mediated injury in vitro. J Neurosci 16:4069-4079.

Chase RA, Pearson S, Nunn P, Lantos PL (1985) Comparative toxicities of $\alpha$ - and $\beta$ - $N$-oxalyl-L- $\alpha, \beta$-diaminoproprionic acids to rat spinal cord. Neurosci Lett 55:89-94.

Cheng B, Mattson MP (1994) NT-3 and BDNF protect CNS neurons against metabolic/excitotoxic insults. Brain Res 640:56-67.

Chiu AY, Chen EW, Loera S (1994) Distinct neurotrophic responses of axotomized motor neurons to BDNF and CNTF in adult rats. NeuroReport 5:693-696.

Cohen RI, Marmur R, Norton WT, Mehler MF, Kessler JA (1996) Nerve growth factor and neurotrophin-3 differentially regulate the proliferation and survival of developing rat brain oligodendrocytes. J Neurosci 16:6433-6442.

Condorelli DF, Salin T, Dell'Albani P, Mudo G, Corsaro M, Timmusk T, Metsis M, Belluardo N (1995) Neurotrophins and their trk receptors in cultured cells of the glial lineage and in white matter of the central nervous system. J Mol Neurosci 6:237-248.

Conover JC, Erickson JT, Katz DM, Bianchi LM, Poueymirou WT, McClain J, Pan L, Helgren M, Ip NY, Boland P, Friedman B, Wiegand S, Vejsada R, Kato AC, DeChiara TM, Yancopoulos GD (1995) Neuronal deficits, not involving motor neurons, in mice lacking BDNF and/or NT4. Nature 375:235-238.

Diener PS, Bregman BS (1994) Neurotrophic factors prevent the death of CNS neurons after spinal cord lesions in newborn rats. NeuroReport 5:1913-1917.

Dreyfus CF, Dai X, Lercher LD, Racey BR, Friedman WJ, Black IB (1999) Expression of neurotrophins in the adult spinal cord in vivo. J Neurosci Res 56:1-7.

Dugich-Djordjevic MM, Tocco G, Lapchak PA, Pasinetti GM, Najm I, Baudry M, Hefti F (1992) Regionally specific and rapid increases in brain-derived neurotrophic factor messenger RNA in the adult rat brain following seizures induced by systemic administration of kainic acid. Neuroscience 47:303-315.

Elkabes S, DiCicco-Bloom EM, Black IB (1996) Brain microglia/macrophages express neurotrophins that selectively regulate microglial proliferation and function. J Neurosci 16:2508-2521.

Ernfors P, Bengzon J, Kokaia A, Persson H, Lindvall O (1991) Increased levels of messenger RNAs for neurotrophic factors in the brain during kindling epileptogenesis. Neuron 7:165-176.

Ernfors P, Merlio J-P, Persson H (1992) Cells expressing mRNA for neurotrophins and their receptors during embryonic rat development. Eur J Neurosci 3:1140-1158.

Ernfors P, Lee KF, Jaenisch R (1994) Mice lacking brain-derived neurotrophic factor develop with sensory deficits. Nature 368:147-150.

Faden AI, Lemke M, Simon RP, Nobel LJ (1988) N-Methyl-D-Aspartate antagonist MK801 improves outcome following traumatic spinal cord injury in rats: behavioral, anatomic, and neurochemical studies. J Neurotrauma 5:33-45.

Faden AI, Ellison JA, Noble LJ (1990) Effects of competitive and noncompetitive NMDA receptor antagonists in spinal cord injury. Eur J Pharmacol 175:165-174.

Friedman B, Hockfield S, Black JA, Woodruff KA, Waxman SG (1989) In situ demonstration of mature oligodendrocytes and their processes: an immunocytochemical study with a new monoclonal antibody, Rip. Glia 2:380-390.

Friedman B, Kleinfeld D, Ip NY, Verge VMK, Moulton R, Boland P, Zlotchenko E, Lindsay RM, Liu L (1995) BDNF and NT-4/5 exert neurotrophic influences on injured adult spinal motor neurons. J Neurosci 15:1044-1056.

Frim DM, Short MP, Rosenberg WS, Simpson J, Breakfield XO, Isacson O (1993) Local protective effects of nerve growth factor-secreting fibroblasts against excitotoxic lesions in the rat striatum. J Neurosurg $78: 267-273$.

Frisen J, Verge VM, Cullheim S, Persson H, Fried K, Middlemas DS, Hunter T, Hokfelt T, Risling M (1992) Increased levels of trkB mRNA and trkB protein-like immunoreactivity in the injured rat and cat spinal cord. Proc Natl Acad Sci USA 89:11282-11286.

Frisen J, Arvidsson U, Lindholm T, Fried K, Verge VM, Cullheim S, Hokfelt T, Risling M (1993) trkC expression in the injured rat spinal cord. NeuroReport 5:349-352.

Funakoshi H, Frisen J, Barbany G, Zachrisson O, Verge VM, Persson H (1993) Differential expression of mRNAs for neurotrophins and their receptors after axotomy. J Cell Biol 123:455-465.

Funakoshi H, Belluardo N, Arenasa E, Yamamoto Y, Casabona A, Persson H, Ibanez CF (1995) Muscle-derived neurotrophin-4 as an activity-dependent trophic signal for adult motor neurons. Science 268:1495-1499.

Furukawa S, Furukawa Y, Satoyoshi E, Hayashi K (1987) Synthesis/ secretion of nerve growth factor is associated with cell growth in cultured mouse astroglial cells. Biochem Biophys Res Commun 142:395-402.

Gall C, Murray K, Isackson PJ (1991) Kainic acid-induced seizures stimulate increased expression of nerve growth factor mRNA in rat hippocampus. Mol Brain Res 9:113-123.

Gall C (1992) Regulation of brain neurotrophin expression by physiological activity. Trends Pharmacol Sci 13:401-403.

Ghosh A, Carnahan J, Greenberg ME (1994) Requirement for BDNF in activity-dependent survival of cortical neurons. Science 263:1618-1623.

Giehl KM, Tetzlaff W (1996) BDNF and NT-3, but not NGF, prevent axotomy-induced death of rat corticospinal neurons in vivo. Eur J Neurosci 8:1167-1175.

Gilad GM, Gilad VH (1995) Chemotaxis and accumulation of nerve growth factor by microglia and macrophages. J Neurosci Res 41:594-602.

Gomez-Pinilla F, Tram H, Cotman CW, Nieto-Sampedro M (1989) Neuroprotective effect of MK-801 and U-50488H after contusive spinal cord injury. Exp Neurol 104:118-124.

Hayashi M, Ueyama T, Tamaki T, Senba E (1997) Expression of neurotrophin and IL-1 $\beta$ mRNAs following spinal cord injury and the effects of methylprednisolone treatment. Kaibogaku Zasshi 72:209-213.

Henderson CE, Camu W, Mettling C, Gouin A, Poulsen K, Karihaloo M, Rullamas J, Evans T, McMahon SB, Armanini MP, Berkemeier L, Phillips HS, Rosenthal A (1993) Neurotrophins promote motor neuron survival and are present in embryonic limb bud. Nature 363:266-270.

Houlgatte R, Mallat M, Brachet P, Prochiantz A (1989) Secretion of nerve growth factor in cultures of glial cells and neurons derived from different regions of the mouse brain. J Neurosci Res 24:143-152.

Hughes RA, Sendtner M, Thoenen H (1993) Members of several gene families influence survival of rat motoneurons in vitro and in vivo. J Neurosci Res 36:663-671.

Hugon J, Vallat JM, Spencer PS, Leboutet MJ, Barthe D (1989) Kainic acid induces early and late delayed degenerative neuronal changes in rat spinal cord. Neurosci Lett 104:258-262. 
Hutton L, deVellis J, Perez Polo JR (1992) Expression of p75NGFR, TrkA, and TrkB mRNA in C6 glioma and type I astrocyte cultures. J Neurosci Res 32:375-383.

Ip NY, Ibanez CF, Nye SH, McClain J, Jones PF, Gies DR, Belluscio L, Le Beau MM, Espinosa III R, Squinto SP, Persson H, Yancopoulos G (1992) Mammalian neurotrophin-4: structure, chromosomal localization, tissue distribution and receptor specificity. Proc Natl Acad Sci USA 89:3060-3064.

Isackson PJ, Huntsman MM, Murray KD, Gall CM (1991a) BDNF mRNA expression is increased in adult rat forebrain after limbic seizures: temporal patterns of induction distinct from NGF. Neuron 6:937-948.

Isackson PJ, Towner MD, Huntsman MM (1991b) Comparison of mammalian, chicken and Xenopus brain-derived neurotrophic factor coding sequences. FEBS Lett 2:260-264.

Isackson PJ (1995) Trophic factor response to neuronal stimuli or injury. Curr Opin Neurobiol 5:350-357.

Jhaveri S, Erzumlu RS, Friedman B, Schneider GE (1992) Oligodendrocytes and myelin formation along the optic tract of the developing hamster: an immunohistochemical study using the Rip antibody. Glia 6:138-148.

Jones KR, Farinas I, Backus C, Reichardt LF (1994) Targeted disruption of the BDNF gene perturbs brain and sensory neuron development but not motor neuron development. Cell 76:989-999.

Junger H, Varon S (1997) Neurotrophin-4 (NT-4) and glial cell linederived neurotrophic factor (GDNF) promote the survival of corticospinal motor neurons of neonatal rats. Brain Res 762:56-60.

Kaal ECA, Joosten EAJ, Bar PR (1997) Prevention of apoptotic motoneuron death in vitro by neurotrophins and muscle extract. Neurochem Int 31:193-201.

Kishino A, Ishige Y, Tatsuno T, Nakayama C, Noguchi H (1997) BDNF prevents and reverses adult rat motor neuron degeneration and induces axonal outgrowth. Exp Neurol 144:273-286.

Klein R, Silos-Santiago I, Smeyne RJ, Lira SA, Brambilla R, Bryant S, Zhang L, Snider WD, Barbacid M (1994) Disruption of neurotrophin-3 receptor gene trkC eliminates Ia muscle afferents and results in abnormal movements. Nature 368:249-251.

Koliatsos VE, Crawford TO, Price DL (1991) Axotomy induces nerve growth factor receptor immunoreactivity in spinal motor neurons. Brain Res 549:297-304.

Koliatsos VE, Clatterbuck RE, Winslow JW, Cayouette MH, Price DL (1993) Evidence that brain-derived neurotrophic factor is a trophic factor for motor neurons in vivo. Neuron 10:359-367.

Koliatsos VE, Cayouette MH, Berkemeier LR, RE C, Price DL, Rosenthal A (1994) Neurotrophin 4/5 is a trophic factor for mammalian facial motor neurons. Proc Nat Acad Sci USA 91:3304-3308.

Kumar S, de Vellis J (1996) Neurotrophin activates signal transduction in oligodendroglial cells: expression of functional TrkC receptor isoforms. J Neurosci Res 44:490-498.

Levine ES, Dreyfus CF, Black IB, Plummer MR (1996) Selective role for trkB neurotrophin receptors in rapid modulation of hippocampal synaptic transmission. Mol Brain Res 38:300-303.

Li L, Oppenheim RW, Lei M, Houenou LJ (1994) Neurotrophic agents prevent motoneuron death following sciatic nerve section in the neonatal mouse. J Neurobiol 25:759-766.

Liu X, Ernfors P, Wu H, Jaenisch R (1995) Sensory but not motor neuron deficits in mice lacking NT4 and BDNF. Nature 375:235-238.

Liu Y, Kim D, Himes T, Chow SY, Schallert T, Murray M, Tessler A, Fischer I (1999) Transplants of fibroblasts genetically modified to express BDNF promote regeneration of adult rubrospinal axons and recovery of forelimb function. J Neurosci 19:4370-4387.

Maisonpierre PC, Belluscio L, Friedman B, Alderson RF, Wiegand SJ, Furth ME, Lindsay RM, Yancopoulos GD (1990a) NT-3, BDNF, and NGF in the developing rat nervous system: parallel as well as reciprocal patterns of expression. Neuron 5:501-509.

Maisonpierre PC, Belluscio L, Squinto S, Ip NY, Furth ME, Lindsay RM, Yancopoulos GD (1990b) Neurotrophin-3: a neurotrophic factor related to NGF and BDNF. Science 247:1446-1451.

Marsala M, Sorkin LS, Yaksh TL (1994) Transient spinal ischemia in rat: characterization of spinal cord blood flow, extracellular amino acid release, and concurrent histopathological damage. J Cereb Blood Flow Metab 14:604-614.

Martinez-Arizala A, Rigamonti DD, Long JB, Kraimer JM, Holaday JW (1990) Effects of NMDA receptor antagonists following spinal ischemia in the rabbit. Exp Neurol 108:232-240.
Matute C (1998) Characteristics of acute and chronic kainate excitotoxic damage to the optic nerve. Proc Natl Acad Sci USA 95:10229-10234.

Matute C, Sanchez-Gomez MV, Martinez-Millan L, Miledi R (1997) Glutamate receptor-mediated toxicity in optic nerve oligodendrocytes. Proc Natl Acad Sci USA 94:8830-8835.

McDonald JW, Althomsons SP, Hyrc KL, Choi DW, Goldberg MP (1998) Oligodendrocytes from forebrain are highly vulnerable to AMPA/kainate receptor-mediated excitotoxic injury. Nat Med 4:291-297.

McTigue DM, Horner PJ, Stokes BT, Gage FH (1998) Neurotrophin-3 and brain-derived neurotrophic factor induce oligodendrocyte proliferation and myelination of regenerating axons in the contused adult rat spinal cord. J Neurosci 18:5354-5365.

Mentis GZ, Greensmith L, Vrbova G (1993) Motoneurons destined to die are rescued by blocking $N$-methyl-D-aspartate receptors by MK- 801 . Neuroscience 54:283-285.

Merlio J-P, Ernfors P, Persson H (1992) Molecular cloning of rat trkC and distribution of cells expressing messenger RNAs for members of the trk family in the rat central nervous system. Neuroscience 51:513-532.

Molander C, Grant G (1995) Spinal cord cytoarchitecture. In: The rat nervous system (Paxinos G, ed), pp 39-45. San Diego: Academic.

Nag S, Riopelle RJ (1990) Spinal neuronal pathology associated with continuous infusion of $N$-methyl-D-aspartate in the rat. Acta Neuropathol 81:7-13.

Olney JW (1978) Neurotoxicity of excitatory amino acids. In: Kainic acid as a tool in neurobiology (McGeer EG, Olney JW, eds), pp 95-121. New York: Raven.

Oppenheim RW, Qin-Wei Y, Prevette D, Yan Q (1992) Brain-derived neurotrophic factor rescues developing avian motoneurons from cell death. Nature 360:755-757.

Peyronnard JM, Charron LF, Lavoie J, Messier JP (1986) Motor, sympathetic and sensory innervation of rat skeletal muscles. Brain Res 373:288-302.

Piehl F, Frisen J, Risling M, Hokfelt T, Cullheim S (1994) Increased trkB mRNA expression by axotomized motoneurones. NeuroReport 5:697-700.

Pisharodi M, Nauta HJ (1985) An animal model for neuron-specific spinal cord lesions by the microinjection of $N$-methyl-aspartate, kainic acid and quisqualic acid. Appl Neurophysiol 48:226-233.

Rokkas CK, Helfrich LRJ, Lobner DC, Choi DW, Kouchoukos NT (1994) Dextrorphan inhibits the release of excitatory amino acids during spinal cord ischemia. Ann Thorac Surg 58:312-319.

Rothstein JD, Tsai G, Kuncl RW, Clawson L, Cornblath DR, Drachman DB, Pestronk A, Stauch BL, Coyle JT (1990) Abnormal excitatory amino acid metabolism in amyotrophic lateral sclerosis. Ann Neurol 28:18-25.

Rudge JS, Alderson RF, Pasnikowski EM, McClain J, Ip NY, Lindsay RM (1992) Expression of ciliary neurotrophic factor and the neurotrophins-nerve growth factor, brain derived neurotrophic factor and neurotrophin 3-in cultured rat hippocampal astrocytes. Eur J Neurosci 4:459-471.

Scarisbrick IA, Jones EG, Isackson P (1993) Coexpression of mRNAs for NGF, BDNF, and NT-3 in the cardiovascular system of the pre- and postnatal rat. J Neurosci 13:875-893.

Scarisbrick I, Isackson P, Jones EG (1994) Developmental expression of neurotrophins in the spinal cord and limb buds of the rat embryo. Soc Neurosci Abstr 20:539.2.

Scarisbrick IA, Towner MD, Isackson PJ (1997) Nervous system specific expression of a novel serine protease: regulation in the adult rat spinal cord by excitotoxic injury. J Neurosci 17:8156-8168.

Schecterson LC, Bothwell M (1992) Novel roles for neurotrophins are suggested by BDNF and NT-3 mRNA expression in developing neurons. Neuron 9:449-463.

Schnell L, Schneider R, Kolbeck R, Barde YA, Schwab ME (1994) Neurotrophin-3 enhances sprouting of corticospinal tract during development and after adult spinal cord lesion. Nature 367:170-173.

Schwob JE, Fuller T, Price JL, Olney JW (1980) Widespread patterns of neuronal damage following systemic or intracerebral injections of kainic acid. A histological study. Neuroscience 5:991-1014.

Seeburger JL, Tarras S, Natter H, Springer JE (1993) Spinal cord motoneurons express p75NGFR and p145trkB mRNA in amyotrophic lateral sclerosis. Brain Res 621:111-115.

Sendtner M, Schmalbruch H, Stöckli KA, Carroll P, Kreutzberg GW, Thoenen H (1992) Ciliary neurotrophic factor prevents degeneration 
of motor neurons in mouse mutant progressive motor neuronopathy. Nature 358:502-504.

Shigeno T, Mima T, Takakura K, Graham DI, Kato G, Hashimoto Y, Furukawa S (1991) Amelioration of delayed neuronal death in hippocampus by nerve growth factor. J Neurosci 11:2914-2919.

Silos-Santiago I, Fagan AM, Garber M, Fritzch B, Barbacid M (1997) Severe sensory deficits but normal CNS development in newborn mice lacking TrkB and TrkC tyrosine protein kinase receptors. Eur J Neurosci 9:2045-2056.

Simon RP, Swan JH, Griffiths T, Meldrum BS (1984) Blockade of $\mathrm{N}$-methyl-D-aspartate receptors may protect against ischemic damage in the brain. Science 226:850-852.

Snider WD (1994) Functions of the neurotrophins during nervous system development: what the knockouts are teaching us. Cell 77:627-638.

Stewart GR, Olney JW, Pathikonda M, Snider WD (1991) Excitotoxicity in the embryonic chick spinal cord. Ann Neurol 30:758-766.

Thoenen H (1991) The changing scene of neurotrophic factors. Trends Neurosci 14:1650-170.

Timmusk T, Palm KM, M, Reintam T, Paalme V, Saarma M, Persson H (1993) Multiple promoters direct tissue-specific expression of the rat BDNF gene. Neuron 10:475-489.

Tuszynski MH, Mafong E, Meyer S (1996) Central infusions of brainderived neurotrophic factor and neurotrophin-4/5, but not nerve growth factor and neurotrophin-3, prevent loss of the cholinergic phenotype in injured adult motor neurons. Neuroscience 71:761-777.

Vejsada R, Sagot Y, Kato AC (1994) BDNF-mediated rescue of axotomized motor neurones decreases with increasing dose. NeuroReport 5:1889-1892.

Vejsada R, Sagot Y, Kato AC (1995) Quantitative comparison of the transient rescue effects of neurotrophic factors on axotomized motoneurons in vivo. Eur J Neurosci 7:108-115.

Wang XH, Poo MM (1997) Potentiation of developing synapses by postsynaptic release of neurotrophin-4. Neuron 19:825-835.

Wong V, Arriaga R, Ip NY, Lindsay RM (1993) The neurotrophins BDNF, NT-3 and NT-4/5, but not NGF, up-regulate the cholinergic phenotype of developing motor neurons. Eur J Neurosci 5:466-474.

Wrathall JR, Choiniere D, Teng YD (1994) Dose-dependent reduction of tissue loss and functional impairment after spinal cord trauma with the AMPA/kainate antagonist NBQX. J Neurosci 14:6598-6607.

Yan Q, Elliot J, Snider WD (1992) Brain-derived neurotrophic factor rescues spinal motor neurons from axotomy-induced cell death. Nature 360:753-755.

Yan Q, Matheson C, Lopez OT, Miller JA (1994) The biological responses of axotomized adult motoneurons to brain-derived neurotrophic factor. J Neurosci 14:5281-5291. 